\title{
Eco-efficient production of spring barley in a changed climate: A Life Cycle Assessment including primary data from future climate scenarios
}

Niero, Monia; Ingvordsen, Cathrine Heinz; Peltonen-Sainio, Pirjo; Jalli, Marja; Lyngkjær, Michael F.; Hauschild, Michael Zwicky; Bagger Jørgensen, Rikke

\section{Published in:}

Agricultural Systems

Link to article, DOI:

10.1016/j.agsy.2015.02.007

Publication date:

2015

Document Version

Peer reviewed version

Link back to DTU Orbit

Citation (APA):

Niero, M., Ingvordsen, C. H., Peltonen-Sainio, P., Jalli, M., Lyngkjær, M. F., Hauschild, M. Z., \& Bagger Jørgensen, R. (2015). Eco-efficient production of spring barley in a changed climate: A Life Cycle Assessment including primary data from future climate scenarios. Agricultural Systems, 136, 46-60. https://doi.org/10.1016/j.agsy.2015.02.007

\section{General rights}

Copyright and moral rights for the publications made accessible in the public portal are retained by the authors and/or other copyright owners and it is a condition of accessing publications that users recognise and abide by the legal requirements associated with these rights.

- Users may download and print one copy of any publication from the public portal for the purpose of private study or research.

- You may not further distribute the material or use it for any profit-making activity or commercial gain

- You may freely distribute the URL identifying the publication in the public portal 
Eco-efficient production of spring barley in a changed climate: a Life Cycle Assessment including primary data from future climate scenarios

Monia Niero, $^{\text {a,b, }}$, Cathrine H. Ingvordsen ${ }^{\mathrm{a}}$, Pirjo Peltonen-Sainio ${ }^{\mathrm{c}}$, Marja Jalli ${ }^{\mathrm{c}}$, Michael F. Lyngkjær $^{\mathrm{d}}$, Michael Z. Hauschild ${ }^{\mathrm{b}}$, Rikke B. Jørgensen ${ }^{\mathrm{a}}$

${ }^{\text {a }}$ Center for Ecosystems and Environmental Sustainability, Department of Chemical and Biochemical Engineering, Technical University of Denmark, Frederiksborgvej 399, 4000 Roskilde, Denmark

${ }^{\mathrm{b}}$ Division for Quantitative Sustainability Assessment, Department of Management Engineering, Technical University of Denmark, Produktionstorvet, 2800 Kgs. Lyngby, Denmark

${ }^{\mathrm{c}}$ Natural Resources Institute Finland (Luke), Natural Resources and Bioproduction, 31600 Jokioinen, Finland

${ }^{\mathrm{d}}$ University of Copenhagen, Department of Plant and Environmental Sciences, Thorvaldsensvej 40, 1871 Frederiksberg C, Denmark

* Corresponding author: Monia Niero telephone: +45 26914347, email: $\underline{\text { monni@ dtu.dk }}$ E-mail addresses: C.H. Ingvordsen (cahi@kt.dtu.dk); P. Peltonen-Sainio (pirjo.peltonensainio@1uke.fi); Marja Jalli (marja.jalli@1uke.fi); Michael F. Lyngkjær (mlyn@plen.ku.dk);

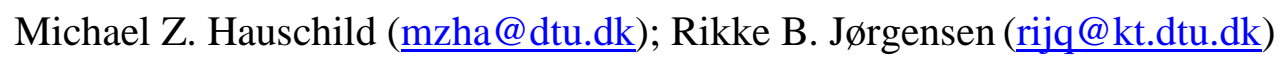




\section{$\underline{\text { Abstract }}$}

The paper has two main objectives: (i) to assess the eco-efficiency of spring barley cultivation for malting in Denmark in a future changed climate $\left(700 \mathrm{ppm}\left[\mathrm{CO}_{2}\right]\right.$ and $\left.+5^{\circ} \mathrm{C}\right)$ through $\mathrm{Life}$ Cycle Assessment (LCA) and (ii) to compare alternative future cultivation scenarios, both excluding and including earlier sowing and cultivar selection as measures of adaptation to a changed climate. A baseline scenario describing the current spring barley cultivation in Denmark was defined, and the expected main deviations were identified (differences in pesticide treatment index, modifications in nitrate leaching and change in crop yield). The main input data originate from experiments, where spring barley cultivars were cultivated in a climate phytotron under controlled and manipulated treatments. Effects of changed climate on both crop productivity and crop quality were represented, as well as impacts of predicted extreme events, simulated through a long heat-wave. LCA results showed that the changed climatic conditions will likely increase the negative impacts on the environment from Danish spring barley cultivation, since all environmental impact categories experienced increased impact for all investigated scenarios, except under the very optimistic assumption that the pace of yield improvement by breeding in the future will be the same as it was in the last decades. The main driver of the increased environmental impact was identified as the reduction in crop yield. Therefore, potential adaptation strategies should mainly focus on maintaining or improving crop productivity. The LCA also showed that selection of proper cultivars for future climate conditions including the challenge from extreme events is one of the most effective ways to reduce future environmental impacts of spring barley. Finally, if yield measurements are based on relative protein content, the negative effects of the future climate seem to be reduced.

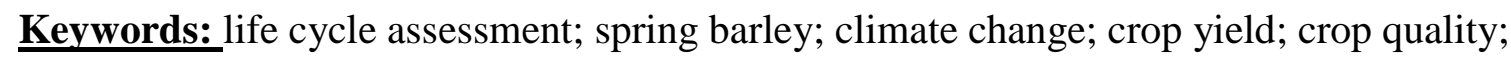
adaptation 


\section{Introduction}

Crop production is expected to respond differently to climate change according to latitude. From the survey by Olesen et al. (2011) involving European agri-climatic and agronomy experts, northern and north-western Europe emerged as the areas with main gains and challenges with regard to climate change. The implications of climate change for crop production are manifold, including both direct effects on crop productivity and crop quality through changes in temperature, concentration of carbon dioxide $\left[\mathrm{CO}_{2}\right]$ in the atmosphere and rainfall, as well as indirect effects on crop yields due to pests and pathogens (Newton et al., 2011) or environmental pollution such as leaching of fertilizer and pesticides (Olesen et al., 2011). The direct climate change impacts on crop productivity have dominated as research topic (Estes et al., 2013; Olesen and Bindi, 2002; Olesen et al., 2004). Still a lot of knowledge is needed on more diverse sets of genotypes of many crop species, but the research on the combined effect of changes in climatic factors on pests, weeds and plant diseases is even more scarce (Porter et al., 2013). Climate change impacts on crop quality are also rarely assessed, even though this may have increasing relevance due to its consequences to food security (Olesen et al., 2011). Furthermore, little attention has been given to the effects of changes in frequency of extreme events (Olesen et al., 2011), despite the likelihood that heat waves and torrential rains will occur with a higher frequency and longer duration in the future, as reported by the Intergovernmental Panel on Climate Change (Collins et al., 2013). Most studies addressing the effects of climate change on cropping systems use crop simulation modelling (Doltra et al., 2012; Estes et al., 2013; Olesen and Bindi, 2002; Smith et al., 2013; White et al., 2011). However, there has been little effort to include effects of both crop growth and environmental sustainability from an ecosystem perspective (Hörtenhuber et al., 2014; Olesen et al., 2011; Pittelkow et al., 2013; Tendall and Gaillard, 2015). The interlinked role of sustainable management of natural resources and climate actions has been strengthened in the recently revised European Common Agricultural Policy (DG Agriculture and Rural Development, 2013). Moreover, in a Northern European country like Denmark the commitment to sustainable agriculture is one of the pillars of the national agricultural policy (Natur- og Landbrugskommissionen, 2013). 
In Denmark, almost half of the cropland is cultivated with barley (Hordeum vulgare L.), respectively $42 \%$ spring and 7\% winter barley (Statistics Denmark, 2014a), and this crop is expected to have an important share of cropland in the future as well. Spring barley is cultivated for two main purposes in Denmark: production of feed grain and barley malt. The latter is the preferred option from the farmers' economic perspective, therefore their first choice is to use cultivars with a lower protein content which is more suited for malt. If they are not able to achieve the sufficient quality for malt, they will sell their harvest as fodder barley at a lower price. To develop strategies for a more sustainable Danish agriculture, the assessment of the environmental impacts associated with spring barley production system for malting in a changed climate earns high priority.

In developing sustainability-oriented agricultural practices Foley et al. (2011) recommend four principles: (1) adopting eco-efficient solutions; (2) addressing trade-offs through improved management decisions; (3) investigating multiple paths, e.g. conventional agriculture, genetic modification and organic farming; (4) increasing the resilience of the food systems. The tool which can holistically assess all these four issues is Life Cycle Assessment (LCA), which aims to quantify the potential environmental impacts of a product system's inputs and outputs during its life cycle (ISO, 2006a). Due to its systemic approach it is capable to avoid the shifting of a potential environmental burden between life cycle stages or different categories of environmental impact. Recently, LCA has been applied in a number of studies to compare current barley production and management alternatives (Fallahpour et al., 2012; Fedele et al., 2014; Korsaeth et al., 2014; Roer et al., 2012), but the use of LCA to predict how the environmental impacts of barley cultivation will respond to changing climate has been very limited (Dijkman, 2013; Tendall and Gaillard, 2015). The definition of LCAbased forecasting scenarios is not straightforward, since predicting future system adaptations and gathering data not yet available are challenging tasks. Dijkman (2013) modelled the environmental impacts of barley cultivation in Denmark under current and future (year 2050) climatic conditions according to IPCC 2007 A1B scenario. Barley yield emerged as the main driver for the impacts, and future crop yields were estimated through interpolations from the dynamic FASSET crop model (Doltra et al., 2012). Since the lack of primary data is one of the most important drawbacks affecting the reliability of LCA studies (Reap et al., 2008), and 
particularly agricultural LCAs (Notarnicola et al., 2012), the assessment of environmental impacts of future systems should rely on measured data from the system studied. This is rarely possible for future agricultural systems, but in our study crop yield and crop quality data from manipulated experiments, where plant material was screened in realistic future climate scenarios and exposed to realistic extreme events, have been the main input to the LCA. Basing LCA on primary data is the key to provide policy makers with reliable suggestions for prioritizing interventions aiming to climate change adaptation. However we acknowledge that also non-climatic, socio-economic and political factors will influence the adaptation of agricultural systems to climate change, but the implications of these aspects lie outside the scope of our study, which has two objectives:

1. To assess the eco-efficiency of spring barley cultivation in a future changed climate in Denmark using LCA; the main input data originate from experiments mimicking a worst case climate change, i.e. double $\left[\mathrm{CO}_{2}\right]$ and $+5^{\circ} \mathrm{C}$, expected in Northern Europe by the end of the century according to IPCC 2007 A1FI scenario. Both direct and indirect effects of changed climate on crop cultivation were considered, as well as the influence of climate change on crop quality, and implications of heat waves as an example of extreme events;

2. To compare different scenarios for spring barley cultivation under a future climate, both excluding and including adaptation measures, such as earlier sowing and cultivar selection, in order to provide policy makers with means to control the potential environmental impacts of this production system. 


\section{Materials and methods:}

The LCA methodology was applied to this case study by following the ISO 14040-44 standards (ISO, 2006a, 2006b). An LCA study consists of four phases: (1) goal and scope definition, (2) life cycle inventory, (3) life cycle impact assessment and (4) life cycle interpretation. The approach we followed to deal with the quantification of many unknown aspects and define consistent future scenarios, was based on the following steps:

1. Definition of a baseline scenario describing the current spring barley cultivation in Denmark;

2. Identification of the main deviations from the current cultivation leading to the definition of a set of alternative scenarios under future climate conditions;

3. Comparison of the alternative scenarios to identify the main drivers of change in future environmental impacts and suggest adaptive measures to compensate for possible deviations.

\subsection{Goal and scope definition}

The goal of the LCA study is to quantify the potential environmental impacts of spring barley production for malting in Denmark under a changed climate (700 ppm $\left[\mathrm{CO}_{2}\right]$ and $\left.+5{ }^{\circ} \mathrm{C}\right)$, a realistic scenario in the second half of this century if the greenhouse gases (GHG) emissions are not reduced significantly. This change of climate is in accordance to the IPCC 2007 A1FI scenario describing a future world of very rapid economic growth, a peak in global population in mid-century, and the rapid introduction of new and more efficient technologies based on fossil intensive energy system (IPCC, 2007). This increase in temperature is aligned with the RCP8.5 (Representative Concentration Pathways) of the IPCC Fifth Assessment Report (Collins et al., 2013), even though there is no exact correspondence, as the cumulative $\mathrm{CO}_{2}$ emission of RCP8.5 is almost double the value considered in the present study. The reason motivating this study was to provide policy makers with means for adapting future spring barley cultivation towards a more sustainable production, based on a quantitative assessment of potential environmental impacts. The product system, i.e. "the collection of unit processes performing a defined function" (ISO, 2006a) as defined by the functional unit, which is the production of $1 \mathrm{~kg}$ of DM (dry matter) barley grain for malting, includes all the agricultural 
operations needed to perform this function in a so-called "from cradle to farm gate" perspective. This functional unit is a reference flow to which the inputs and outputs of the product system are related, both in terms of material flows and potential environmental impacts. For crop systems, a mass-based functional unit, rather than an area-related functional unit is preferred in order to be capable of assessing differences in land use efficiency (Brentrup et al., 2004; Hayashi, 2013). The system boundaries determine, which unit processes shall be included within the LCA. Figure 1 describes the system boundaries of our study using a process flow diagram, including the unit processes and their inter-relationships and main inputs and outputs. The unit processes included in the system boundaries are those commonly considered in cradle to farm gate LCA studies on barley (Fedele et al., 2014; Korsaeth et al., 2014; Roer et al., 2012), i.e. all the field work related processes. The main distinction in spring barley cultivation for feed grain versus malt resides in the different application of $\mathrm{N}$ fertilizer. Besides, cultivars chosen with malting as the primary target normally should have a lower protein contents than those used for feed. Therefore, fertilizer application should also be adjusted, so that the malting barley will hold a protein contents between 9.5-11\% (Knowledge Centre for Agriculture, 2013). The field related processes can be subdivided into four main steps: seed bed preparation (ploughing and harrowing); establishment (fertilizer application, and combined sowing and harrowing), external control agents (herbicide, fungicide and insecticide application), finalization (harvesting and drying), and finally the emissions from the field distinguished between air and water.

\subsection{Life Cycle Inventory (LCI)}

The LCI is an inventory of input and output data related to the functional unit for the system being studied. It is usually performed trough the collection of historical data at regional or national scale describing the product system (Roer et al., 2012) or using data from casespecific farms (Fedele et al., 2014). In the present study we refer to average Danish spring barley cultivation in sandy loam soil, i.e. JB6 of the Danish soil classification (Greve, 2011) assuming conventional farming techniques. The sources of data are manifold: primary data on crop yield from experiments in future climate scenarios (Ingvordsen, 2014), as well as National databases and published data valid within the geographic scope of the study, i.e. 
Denmark (Hamelin et al., 2012; Knowledge Centre for Agriculture, 2013). A summary of the main input according to the selected unit processes and datasets used is reported in Table 1 for the baseline scenario. The unit process data are referring to cultivation area of 1 ha and in the modelling translated into an inventory for the production of the functional unit.

\subsubsection{Experimental data}

A novel aspect of the data collection is that the information on yield and quality of the crop is primary data coming from growing the crop under changed climate conditions. Experimental data were obtained from cultivation of spring barley cultivars in the climate phytotron RERAF (Ris $\varnothing$ Environmental Risk Assessment Facility). In controlled treatments, the effect of elevated temperature, $\left[\mathrm{CO}_{2}\right]$ and $\left[\mathrm{O}_{3}\right]$ as single factors or in combination have been assessed on grain yield. Furthermore, an experiment mimicking an extreme heat-wave around flowering, i.e. the most critical phase for grain set and yield determination, has been performed. The details of the experimental set ups are provided in (Ingvordsen, 2014) and Ingvordsen et al. (2015). For the LCA study, we considered a subset of data, including 13 cultivars listed in Table 2 for which a complete set of experiments has been performed, both under ambient conditions (400 ppm $\left[\mathrm{CO}_{2}\right], 19 / 12{ }^{\circ} \mathrm{C}$ day/night), double-factor treatment (700 $\operatorname{ppm}\left[\mathrm{CO}_{2}\right], 24 / 17{ }^{\circ} \mathrm{C}$ day/night) and a long heat-wave $\left(700 \mathrm{ppm}\left[\mathrm{CO}_{2}\right], 33 / 28{ }^{\circ} \mathrm{C}\right.$ day/night for 10 days). The light regime was 16 hours of light and 8 hours of dark; the temperature was kept constant during the day and during the night, and the experimental values corresponded well with the set point values (Ingvordsen et al., 2015). Among these cultivars we further selected the five cultivars with the highest grain yield under the double-factor treatment, and considered them as a separate group, as reported in Table 2.

Data gathered from RERAF were originally measured in terms of grain yield (g/plant) and were therefore rescaled to represent field data. We performed the conversion considering a pot size of 23 x $23 \mathrm{~cm}$ and 8 plants/pot, with resulting plant density in RERAF of 151.23 plants $/ \mathrm{m}^{2}$, used as converting factor to have yield estimate per $\mathrm{m}^{2}$. Plant density is somewhat higher in the field, but previous studies have shown that seeding rates of $120-280 \mathrm{seed} / \mathrm{m}^{2}$ did not affect grain yield in barley, wheat and oat (Schillinger, 2005). Crop yield data calculated with this procedure refer to ideal, consistent experimental conditions in the climate phytotron 
contrary to those typically fluctuating in the field; therefore cannot be used as such. The average crop yield for spring barley in loamy sand soil in the 5-years interval 2009-2013 in Denmark was 5700 kg/ha (Danish Ministries of Food Agriculture and Fisheries, 2013, 2012, 2011, 2010, 2009). As a consequence crop yield values from RERAF in the combined treatment should be downsized by a scaling factor of 55\% (given by the ratio of actual crop yield to experimental crop yield from the ambient RERAF treatment and then multiplied with crop yield from the double-factor RERAF treatment), for both sets of cultivars considered. The heat-wave experiment was performed using the same cultivars, but as an experiment separated in time and space from the baseline experiment. Therefore, our approach was to calculate the deviation of crop yield in relative terms, between the double treatment without and with heat-wave, for both sets of cultivars. Up-scaling data from RERAF to the field is a valid option, provided that the proportion between yield in the ambient and the future climate scenarios in RERAF will also apply to the present versus future field conditions.

\subsubsection{Agricultural operations}

Based on Hamelin et al. (2012) data for the agricultural operations (ploughing, harrowing, fertilizer application, sowing and harrowing, pesticide application, harvesting and grain drying) were taken from the ecoinvent database (Nemecek and Kägi, 2007). According to Dijkman (2013) and Hamelin et al., (2012), we adjusted diesel consumption to Danish conditions based on the norm values presented by Dalgaard et al. (2001) and assumed lubricating oil consumption for the machinery as a fixed amount $(0.62 \%)$ of the diesel applied (Roer et al., (2012). The amount of fertilizer was based on Danish regulations, considering an average of the nitrogen $(\mathrm{N})$, phosphorus $(\mathrm{P})$ and potassium $(\mathrm{K})$ applied on the field on a 5years interval in the period 2009-2013 (Danish Ministries of Food Agriculture and Fisheries, 2013, 2012, 2011, 2010, 2009). In accordance with Hamelin et al. (2012) we assumed that half of the $\mathrm{N}$ demand is fulfilled by mineral fertilizer and half by animal manure, with respectively $50 \%$ pig slurry and $50 \%$ dairy cattle slurry. This assumption is representative of the average Danish situation, considering that between 2008-2012 the share of Danish farms with pig and cattle has been equal to $45 \%$ (Statistics Denmark, 2014b). In the LCI modelling we considered manure as a waste of animal production systems, therefore assuming its 
production "free" of environmental burden (Nemecek et al., 2011b; Röös et al., 2011), i.e. the emissions from production of manure are allocated to the animal production system, and were not considered in the present study. We followed the approach by Hamelin et al. (2012) and calculated the composition of both pig slurry and dairy cattle slurry ex-storage through mass balances for the 5-years interval 2009-2013 (Poulsen, 2013, 2012a, 2012b, 2010, 2009), considering that for manure not all the applied $\mathrm{N}$ will, during the growing period, end up in an inorganic form available to plants. We took into account the values of the so-called " $\mathrm{N}$ utilization efficiency factors" defined by law for a variety of manure types, i.e. $75 \%$ for pig slurry and 70\% for cow slurry (Danish Ministries of Food Agriculture and Fisheries, 2012). Following Hamelin et al. (2012) we assumed that slurry spreading is performed by trail hose application, i.e. representative of average Danish conditions. The mineral fertilizer used, both in practice and in the experimental set, is an NPK fertilizer in the distribution 21-3-10 with S and $\mathrm{Mg}$, but was modelled based on single nutrient fertilizers, namely calcium ammonium nitrate (CAN), single superphosphate (SSP) and potassium chloride, since the production of NPK fertilizer is not included in the ecoinvent database (Nemecek and Kägi, 2007). The amount of each single nutrient fertilizer was calculated as a difference between the current upper ceiling for the amount allowed by the Danish regulation and the amount provided by the animal slurry. Regarding K content, since the need was fulfilled by animal slurry, no further K fertilizer was added, following the approach suggested by Hamelin et al. (2012).

External control agents include the application of herbicides, fungicides, and insecticides. Data on the production of mineral fertilizers and pesticide were taken from ecoinvent database (Sutter, 2010). The choice of active agents, dosages applied and number of sprayings was based on general spraying recommendations (pers. comm. M. Haastrup, Knowledge Centre for Agriculture, DK). Emissions into air, groundwater and surface water from pesticide application were modeled with PestLCI 2.0 (Dijkman et al., 2012). According to Roer et al. (2012) machinery production has a non-negligible influence on the LCA results, differently from construction of buildings, therefore the first was included and the last excluded. Rainwater use is not considered as an input in LCA (Milà i Canals et al., 2008), and since the Danish cropping systems are rain-fed, there is no water use in the inventory. As a secondary output from harvesting, it was assumed that straw is incorporated in the soil. In the RERAF 
experiments plants were grown in a standard soil mixture (Pindstrup no. 6). All harvested grain was assumed to be dried in a grain dryer where the water content of the grain was reduced to $15 \%$, considering the energy requirement reported by Edström et al. (2005).

\subsubsection{Emissions from field}

The unit processes "field emissions into air/water" include the emissions due to fertilizer application as well as crop residues, which take place throughout the year. The details of the emission factors are reported in Table 1. Emissions of $\mathrm{N}_{2} \mathrm{O}$ from IPCC default factors (IPCC, 2006) in Denmark approximately correspond to measured emissions (Chirinda et al., 2010), except for the fraction of applied organic $\mathrm{N}$ fertilizer materials that volatilizes as $\mathrm{NH}_{3}$ and $\mathrm{NO}_{\mathrm{X}}$, i.e. Frac $\mathrm{GASM}_{\mathrm{S}}$, which according to Denmark's National Emission Inventory report (Nielsen et al., 2013) is equal to $0.019 \mathrm{~kg}$ of $\mathrm{N}$ volatilized $/ \mathrm{kg} \mathrm{N}$ applied.

\subsection{Life Cycle Impact Assessment (LCIA)}

The purpose of the LCIA is to understand the potential environmental impacts of the system, given the LCI results. The choice of the LCIA method is scope-dependent, but some recommendations have recently been provided by European Commission’s Joint Research Center and have therefore been followed (Hauschild et al. 2013). We did not include the whole set of impact categories, but instead focused on a selection of impact categories at midpoint level relevant for crop production (Korsaeth et al., 2014; Nemecek et al., 2011a, 2011b; Roer et al., 2012):

- climate change (CC) expressed in $\mathrm{kg} \mathrm{CO}_{2}$ eq., according to IPCC baseline model of 100 years (Forster et al., 2007);

- human toxicity, cancer (HT-c) and non-cancer effects (HT-nc), expressed in comparative toxic unit for humans $\left(\mathrm{CTU}_{\mathrm{h}}\right)$ based on the USEtox nested multimedia model (Rosenbaum et al., 2008);

- acidification (AC), expressed in terms of $\mathrm{kg}$ molc $\mathrm{H}^{+}$eq., based on Posch et al. (2008);

- freshwater eutrophication (FE) and marine eutrophication (ME), expressed in $\mathrm{P}_{\text {eq. }}$ and $\mathrm{N}_{\text {eq. }}$. respectively, according to the EUTREND model as implemented in ReCiPe LCIA model (Struijs et al., 2013); 
- freshwater ecotoxicity (FET), expressed in comparative toxic unit for ecosystems $\left(\mathrm{CTU}_{\mathrm{e}}\right)$ based on the USEtox model (Rosenbaum et al., 2008) with updated characterization factors for metals (Ba, Be, Cd, Co, Cr (III), Cu (II), Ni, Pb, Zn) as calculated by Dong et al. (2014); - land use (LU), measured in $\mathrm{kg} \mathrm{C} / \mathrm{m}^{2} / \mathrm{a}$, based on the Soil Organic Matter (SOM) model by Milà et al., (2007), which provides a measurement of soil quality;

- water resource depletion (WD), measuring water use related to local water scarcity in $\mathrm{m}^{3}$ water eq, according to the Swiss Ecoscarcity model (Frischknecht et al., 2008);

- mineral \& fossil resource depletion (MFD), referring to mineral and fossil resource scarcity and measured in terms of $\mathrm{Sb}_{\mathrm{eq}}$., based on CML 2002 LCIA model (Guinée et al., 2002).

\subsection{Life Cycle Interpretation}

Life cycle interpretation is the final phase of the LCA, in which the results of both LCI and LCIA are discussed as a basis for conclusions and recommendations in accordance with the goal and scope of the study. It usually includes different techniques to test the robustness of the outcome of the study, i.e. contribution, sensitivity and uncertainty analyses. Contribution analysis aims at identifying the contribution of the different unit processes to the impact; it has been applied considering the unit processes defined in Figure 1 and Table 1. Sensitivity analysis aims at testing relevant hypothesis and their influence on the final outcomes. Since the amount of fertilizers applied will likely affect the yield (Snyder et al., 2009), we performed a sensitivity analysis through a change in the rate of fertilizer application under future scenarios $( \pm 10 \%)$. Furthermore, we considered the effect of climate change on crop quality, performing a further sensitivity analysis with $1 \mathrm{~kg} \mathrm{CP}$ (Crude Protein content) as functional unit, as suggested by Roer et al. (2012).

\subsection{Scenario definition}

A precise description of spring barley cultivation in the future climate is not straightforward as many aspects need to be taken into account. As a consequence no univocal definition of spring barley production under future changed climate can be performed, and therefore seven alternative scenarios are analyzed. These can be grouped in three main sets: scenarios not including adaptation measures (S1, S2), scenarios including adaptation measures (S3, S4, S5) and scenarios mimicking extreme events (S6, S7), as reported in Table 3. 
The identification of the main deviations from the current spring barley cultivation is the key point, dealing with the prediction of future conditions and consequently includes assumptions. We assumed that residue management will remain the same as today, i.e. straw incorporation. It is a reasonable assumption, since in the 5-years interval 2008-2012 the area with straw left on the field has continuously increased in Denmark (Statistics Denmark, 2014c), but straw could be used also for energy, fodder or bedding. However the assessment of these options is outside the scope of the present LCA.

Concerning herbicides, insecticides, and fungicides application under future conditions for all scenarios we assume an increase of $25 \%$ of the treatment index (TI) compared to the current value, based on the predictions in Juroszek \& von Tiedemann (2011). Furthermore, as we cannot make any guess about the types of pesticides which will be developed in the future, we assume that pesticides comparable to current ones will be applied also under future climate conditions. A change in crop protection is one of the most prominent adaptation measures for barley, due to the spread of pests and diseases from warmer zones to northern regions, where the expected higher precipitation might also result in higher infestation pressure from some native diseases, e.g. Fusarium sp. (Olesen et al., 2011).

Since in the experiments mimicking future climate the amount of fertilizer currently applied was used, in the LCI modeling of future scenarios we kept the amount of $\mathrm{N}$ fertilizer per ha constant, considering the same source of nutrients and composition (see scenarios S1-S7 in Table 3). This assumption is valid if manure from pigs and dairy cattle will not change in composition of nutrients, despite of possible changes in feed due to climate change or other external factors.

One of the projected effects of climate change is an increase in $\mathrm{N}$ leaching due to increased precipitation and percolation (Olesen et al., 2011). Based on Jensen \& Veihe (2009) we considered two situations: first a 24\%increase in $\mathrm{N}$ leaching, assuming the same management as today for all set of cultivars (S1) and for the five best yielding cultivars (S2). However, as the potential increase in leaching could result in needs for modification of fertilizer application and crop management practices to comply with EU environmental targets (Olesen et al., 2011), we considered also a further set of scenarios including adaptation measures, where the level of leaching is kept unchanged considering: 
(a) early sowing (Olesen et al., 2012) and decrease in crop yield according to RERAF experiments under double treatment (S3);

(b) cultivation of cultivars with better nutrient efficiency/uptake and same crop yield as today (S4);

(c) cultivation of cultivars with better nutrient efficiency/uptake and better crop yield than today (S5).

Based on Olesen et al. (2011) these actions (changes in cultivars and sowing dates) can be seen as short term adjustments, with prospect of adaptation through cultivar improvement expected to be more important in the case of spring barley. Early sowing affects all other agricultural operations. The change of dates of sowing, application of fertilizer, and harvest has been considered in accordance to Henriksen et al. (2012), based on experiences from current crop management practices for sites in more southern European countries. The timing of pesticide application, being an input to PestLCI 2.0 (Dijkman et al., 2012), has been changed accordingly, therefore assuming that herbicides, insecticides and fungicides will be applied one month earlier. The inclusion of scenarios with improved crop cultivars is based on the evidence that cereal breeders in Europe have in the past succeeded in creating crop cultivars with higher yield potential in combination with improved stress tolerance (Tester and Langridge, 2010). Genetic improvement has been the main reason for the considerable yield increases over the last decades (Peltonen-Sainio et al., 2009; Rötter et al., 2011), therefore we assume that breeders will be able both to develop cultivars assuring the same level of crop yield (S4) and even with better yielding performance (S5). We hypothesize that the pace of yield improvement by breeding in the future will be the same as it was in the last decades; therefore for scenario S5 we consider an annual yield increase of $1.144 \%$ for the next 40 years (Peltonen-Sainio et al., 2009). This last scenario can be used as reference for a non-yield-limited situation, where yield is not limited by environmental constraints or management compared to today. Finally, the scenarios describing the extreme heat-wave event (S6-S7) have the same assumptions as for S1 in terms of $\mathrm{N}$ leaching, but crop yield is adjusted according to the heat-wave experiment in RERAF.

Based on Dalgaard et al. (2011), from now to 2050 a decrease in mineral fertilizer and manure production is expected in Denmark, due to a reduction in conventionally farmed area. Since 
measures to improve the $\mathrm{N}$ use efficiency and effectiveness through better fertilizer management and new technology are already available (Snyder et al., 2009), it is likely that the amount of $\mathrm{N}$ applied in agricultural crop production will be reduced. To test this trend, we considered a reduction of $10 \%$ in the amount of $\mathrm{N}$ fertilizer applied (S8-S10 in Table 4).

On the other hand, in the northern zone there might be a need to increase the nutrient supply and therefore rates of fertilizer in order to match crop requirements (Doltra et al., 2012). We considered three further scenarios (S11-S13 in Table 4) based on 10\% increase in fertilizer application. A difference in the amount of $\mathrm{N}$ fertilizer applied has an influence on both the amount of $\mathrm{N}$ leaching and crop yield. $\mathrm{N}$ leaching has been calculated according to Kristensen et al. (2008) based on the amount of $\mathrm{N}$ applied (S9, S10, S12, S13), and considering an increase of 24\% (Jensen and Veihe, 2009) for S8 and S11. Crop yield in the scenarios with changed $\mathrm{N}$ application was extrapolated considering the correlation between $\mathrm{N}$ applied and crop yield under current climatic conditions (Stoumann et al., 2011), adding the climate change deviation, as measured in RERAF, inherently assuming that the climate-component will be independent of the amount of $\mathrm{N}$ applied. The field emissions into air $\left(\mathrm{NO}_{\mathrm{X}}, \mathrm{N}_{2} \mathrm{O}\right.$ and $\mathrm{NH}_{3}$ ) have been adjusted according to the $\mathrm{N}$ amount applied.

In a further sensitivity analysis a different functional unit $(1 \mathrm{~kg} \mathrm{CP})$ was chosen, which takes into account the quality of the crop. Data on $\%$ of $\mathrm{CP}$ were available from RERAF, as described in Ingvordsen (2014) for all cultivars considered in the study. The average CP content was measured equal to $13.4 \%$ under ambient conditions, and $14.5 \%$ and $14.6 \%$ under the double-factor treatment for the sets of 13 and best 5 yielding cultivars, respectively. 


\section{Results}

The results of the LCIA for the current scenario and the seven alternative scenarios for future barley cultivation under changed climate are presented in Table 5 in absolute numbers and with the $\%$ deviation from the current scenario. Figure 2 reports the results in relative terms, where the scenario with highest value is used as internal normalization reference and given $100 \%$ of the impact with the other scenarios are consequently rescaled.

\subsection{Contribution analysis}

The results of the contribution analysis for current spring barley cultivation are reported in Figure 3, where the contribution of the different unit processes to the total score is reported per impact category. The contribution of fertilizer application is significant for almost all impact categories, except HT-nc, FET and LU. Fertilizer application dominates the impact for HT-c, FE, WD, MFD, but due to different reasons. Mineral fertilizer (CAN and SSP) production affects: HT-c, due to metal $(\mathrm{Cr})$ emission into water; WD, due to water needed in sulfuric acid production for SSP, and MFD, due to metal extraction in manufacturing, while the application of the $\mathrm{P}$ component of mineral fertilizer and manure is the main responsible for the impact on FE. Field emissions into air contribute predominantly to $\mathrm{CC}$, due to $\mathrm{N}_{2} \mathrm{O}$ emissions and $\mathrm{CO}_{2}$ emissions from loss of soil $\mathrm{C}$, and to $\mathrm{AC}$, due to ammonia emissions. Field emissions into water are the main contributor to HT-nc and FET, due to $\mathrm{Cu}$ and $\mathrm{Zn}$ loss deriving from manure application; to $\mathrm{ME}$, due to nitrate emissions and to a lesser extent application of fertilizer and manure ( $\mathrm{N}$ component). Finally, the impact on LU is due to the occupation of arable land. Since the inventory data have been collected per hectare of cultivated area (Table 1) and then converted to the functional unit through the crop yield values in Table 2, the contribution analysis represented in Figure 3 is valid for all impact categories, whose value is only affected by changes in crop yield, i.e. HT-c, AC, LU, WD, and MFD in all future scenarios. For CC, HT-nc and FET small differences (around 1\%) have been detected. For $\mathrm{CC}$ it should be considered that the change of soil $\mathrm{C}$ due to the temperature increase has not been included in the calculation. Significant changes in the contribution analysis among future scenarios and current scenario were found for FE, as detailed in Figure 4. Meanwhile for ME there is a slight variation for S1, S2, S6, S7, i.e. scenarios with increase 
in nitrate leaching, where the contribution of "field emissions into water" increases due to the increased nitrate emission into the marine environment.

\subsection{Sensitivity analysis}

The results of the sensitivity analysis on the amount of fertilizer applied are reported in Figure 5 in terms of deviation from the current scenario. Since for S8 and S9 we assumed the same decreased crop yield, these two scenarios present the same percentage variation for all impact categories except ME, going from $39 \%$ for CC to $74 \%$ for FE. For ME the increase is $+72 \%$ and $+48 \%$ for S8 and S9 respectively, due to the increase in nitrate leaching. The same is the case for S11 and S12, which present a similar trend for all impact categories, except ME, ranging from an increase of $+20 \%$ for LU to $+31 \%$ for HT-c. For ME the increase is $+46 \%$ for S11 (+24\% nitrate leaching) and $+26 \%$ for S12 (current nitrate leaching trend). S10 shows a decrease for all impact categories (from $-0.2 \%$ for LU to $-10 \%$ for CC), while S13 shows a lower increase in impacts compared to S11-S12 (from $+0.2 \%$ for LU to $+11 \%$ for CC). The results of the sensitivity analysis considering $1 \mathrm{~kg} \mathrm{CP}$ as functional unit are reported in Table 6 in absolute terms and including the \% deviation from the current scenario. The variation between the alternative future scenarios and the current scenario with respect to the case with $1 \mathrm{~kg} \mathrm{DM}$ as functional unit is lower, ranging around $+26 /+31 \%$ for S1 and S3, except ME for S1. Compared to the impacts expressed per kg DM, for S2 and S4 there is a reduction of the potential environmental impact between future and current situation, meanwhile for S5 the deviation is higher per $\mathrm{kg} \mathrm{CP}$. 


\section{Discussion}

\subsection{Comparison with other studies}

The LCIA results of current spring barley cultivation in Denmark are aligned with the results of other LCA studies on barley production in northern countries, at least for the directly comparable impact categories, i.e. CC, ME, FE, HT and FET. A direct comparison among the results from different LCA studies is not always straightforward, due to the different system boundaries definition and assumptions. Dijkman (2013) performed a comparative LCA of spring barley under current and future conditions considering spring barley cultivation in Denmark with almost similar assumptions. Due to different modelling assumption (e.g. straw removal with consequent economic allocation to assign the impact between grain and straw), their values for current spring barley production are lower compared to our results, i.e. $44 \%$ lower value of $\mathrm{CO}_{2 \mathrm{eq}}$ of $\mathrm{CC}$ for sandy loam soil. Secondly they didn't include the loss of soil organic C, which in our study accounts for about $20 \%$ of the total impact to CC. With regard to Norwegian conditions, our CC value is lower, respectively $-82 \%$ and $-49 \%$ (Korsaeth et al., 2014; Roer et al., 2012). This is mainly due to the differences in crop yield considered for Norway, i.e. $3750 \mathrm{~kg} \mathrm{DM} / \mathrm{ha}$ (Korsaeth et al., 2014) and $4760 \mathrm{~kg} \mathrm{DM} / \mathrm{ha}$ (Roer et al., 2012), and differences in input, i.e. the exclusion of lime application and changes in SOC (soil organic carbon) due to soil mineralization. In terms of unit processes contribution, our CC results are in accordance with previous studies, which identify field emissions and fertilizer application as the main contributors to the impact (Dijkman, 2013; Korsaeth et al., 2014; Roer et al., 2012). Concerning FE, our results are respectively 52\% and $43 \%$ higher than the results obtained by Dijkman (2013) and Roer et al. (2012), due to the P-component released during cattle manure application, which is not included in these studies. Concerning ME, our results deviate $+29 \%$ from Dijkman (2013) due to the higher level of $\mathrm{N}$ applied by the use of cattle manure, and $-53 \%$ from Roer et al. (2012). Since in the last study the impact on ME is dominated by ammonia and nitrous oxides emissions as well as $\mathrm{N}$ loss, the deviation is probably due to the different contribution of these input flows. Regarding the toxicity impact categories, our values are several orders of magnitude higher than the values obtained by Dijkman (2013), but this is due to the use of different sets of characterization factors (CFs) for Usetox. We indeed included both recommended and interim CFs (EC-JRC-IES, 2011), using 
updated CFs for heavy metals (Dong et al., 2014), meanwhile Dijkman (2013) considered only the recommended set. As a consequence our LCIA includes the contribution of $\mathrm{Cu}$ and $\mathrm{Zn}$ emissions deriving from the application of animal slurry.

\subsection{Consequences to the environment of spring barley production under changed climate}

Our results show that Danish spring barley cultivation under changed climatic conditions (700 ppm $\left[\mathrm{CO}_{2}\right]$ and $+5^{\circ} \mathrm{C}$ ) will likely have adverse effects on environment, since all the impact categories included in the study are expected to increase in the future for all scenarios, except the ideal one (S5). The factors causing an increase in potential impacts are manifold, but the main reason is the decrease in crop yield. The impact categories which are strongest affected by the differences in crop yield are CC, HT-c, AC, LU, WD, MFD. They present similar trend, with the highest difference from the current situation observed in S6 and S7, which simulate the extreme heat-wave event, as reproduced in RERAF. The increase in potential environmental impacts of this selection of impact categories was smaller when the decrease in crop yield was reduced in $\mathrm{S} 1$ representing situation without adaptation measures. If only the best 5 cultivars were considered, the increase in potential environmental impact directly reflected the decrease in crop yield, except for ME and FE, where the highest deviations from current impacts in S1, S6 and S7 were mainly due to an increased leaching of nitrate from the field for $\mathrm{ME}$ and leachate losses of $\mathrm{P}$ and application of mineral fertilizer and manure for FE. The importance of fertilizer application for the environmental impacts of future spring barley cultivation is confirmed by the sensitivity analysis where the applied amount of $\mathrm{N}$ is varied. Since the composition of animal slurry was kept constant in terms of nutrient content, its contribution to comply with the $\mathrm{N}$ requirement of the crop does not change. Therefore, if the overall amount of $\mathrm{N}$ applied to the field varies, it has to be through adjustments of the amount of mineral fertilizer. The two extreme situations reflect conditions, where the amount of mineral N fertilizer was respectively decreased (S8-S9-S10) and increased (S11-S12-S13) compared with the current situation. For the set of scenarios with decreased spreading of mineral N (S8 and S9), there was an increase in the potential impacts due to the accompanying decrease in yield relative to the corresponding scenarios with the current level of $\mathrm{N}$ application, i.e. S1 vs S8, S3 vs S9. This can be compensated for by development of cultivars with the same crop yield at decreased N-input (S10). However, like for S5 this last 
scenario is an ideal one, since genetic improvement in NUE (Nitrogen Use Efficiency) will not be able to alone compensate for decreased $\mathrm{N}$ availability, but other crop management practices are needed to improve $\mathrm{N}$ uptake in future which again may affect the outcome of LCA (pers. comm. P. Peltonen-Sainio, MTT, FIN). In this case there could be a reduction for those impact categories most affected by mineral fertilizer production and application, i.e. CC, HT-c, AC, ME, WD, MFD. An increase in the amount of N applied, and therefore a further increase of the share of mineral fertilizer applied, determines an increase of the impacts, which is lower than the impact increase in the scenario without adaptation (S1). The only scenario with a decrease of the potential environmental impacts for $\mathrm{CC}$ is $\mathrm{S} 10$, which considers cultivars with the same crop yield of today.

The situation is slightly different with $1 \mathrm{~kg} \mathrm{CP}$ as functional unit, since the $\mathrm{CP}$ content was measured to be higher in the future climate. In this case we had three scenarios (S2, S4 and S5) showing lower impacts in the future compared to today. For S4, the parameters considered were the same as today, except the increase in TI. Therefore this option showed a potential reduction in the environmental impacts, due to the greater $\mathrm{CP}$ content. However, from other results obtained from the same set of cultivars (pers. comm. AM Torp, KUScience, DK) it appears that the increase in $\mathrm{CP}$ is possibly due partly to increase in phytic acid. Phytic acid binds the inorganic phosphate (P) so that animals cannot take it up, and excess $\mathrm{P}$ is therefore excreted in the manure. Unless compensated for by adding external phytase to the fodder, the consequence might be an increase in the $\mathrm{P}$ content of pig and dairy cattle slurry, which influences mainly FE and ME impacts categories. Increased protein content represents an adverse effect for malting processes and final beer quality Högy et al. (2013), therefore introducing further uncertainty to spring barley cultivation for malting under future climate change in Denmark.

\subsection{Recommendations for the definition of adaptation strategies}

The quantification of GHG emissions from agriculture is fundamental to identifying solutions that are consistent with the goals of achieving greater resilience in production systems and food security (Olander et al., 2013). However, the assessment of the environmental effects from crop cultivation under climate changed conditions should not be limited to the effects on the global warming impact category, but to a comprehensive set of environmental issues, as 
advocated by the LCA methodology. In our case study for the scenarios with the 5 best yielding cultivars (S2) the difference in CC impact is almost negligible compared to current scenario, but in terms of ME the difference is consistent (19\%). LCA methodology through scenario analysis proved to be effective in achieving this more holistic view in impacts for crop and livestock systems (Leinonen et al., 2013; Tendall and Gaillard, 2015). Different aspects have been included in the scenario definition, i.e. influence of increase of nitrate leaching (S1, S2, S6, S7), increase of the treatment index (S4), as well as difference in crop yield (S1, S2, S3, S5, S6, S7). These aspects affect different impact categories and their influence on the final results indicate, which adaptation strategy should be prioritized to control the overall potential environmental impacts of the future spring barley cultivation in Denmark:

- the influence of the expected increase in pesticide treatment index was not significant in terms of potential impacts on ecotoxicity;

- the impact of nitrate leaching from the future spring barley cultivation on ME necessitates the implementation of adaptation measure;

- the main driver for the adverse environmental impact was the expected reduction in crop yield.

Therefore potential adaptation strategies should mainly focus on sustaining high crop yields in the future climatic conditions. As pointed out by Peltonen-Sainio et al. (2009), Rötter et al. (2011) and Martín et al. (2014), there are two major contributors to yield trends: changes in crop management practices (e.g. shifts in sowing dates) and genetic improvements of cultivars to improve their capacity to cope with the changing climatic constraints and environment, even for temperature increases exceeding $4^{\circ} \mathrm{C}$. With the current germplasm a considerable decrease in potential environmental impacts can be obtained, if the best yielding cultivars are considered, see S2 vs S1 and S7 vs S6. In the identification of adaptation solutions, we took into account only one of the possible changes in crop management, i.e. early sowing (S3). This scenario showed the same potential environmental impacts of S1, since both considered the same crop yield, and the change in the timing of pesticide application did not influence the results. The level of impact in a changed climate could potentially be the same as today, if cultivars that are better able to cope with the climatic constraints are developed and thereby, 
they have at least the same grain yields as today (S4). Furthermore, the great potential of selecting genotypes is proved by the likely reduction in environmental impacts in the ideal scenario where barley cultivars have better nutrient uptake and higher grain yields than today (S5); reductions are even from $40 \%$ to $56 \%$ according to the selected impact category. This example, though sounding partly unrealistic, highlights the importance of putting sufficient efforts in research that sustains breeding of resilient cultivars that are particularly well adapted to the future conditions of a particular region. This is necessary in order to counter the negative effects of climate change on cereal growing in temperate climates, see e.g. Brisson et al. (2010) for wheat in France, caused by heat stress during grain filling and drought during stem elongation.

\subsection{Limitations and perspectives}

LCA results are strongly affected by the modelling assumptions and the inherent uncertainty connected with the definition of future scenarios. Some of the limitations of our study are that certain aspects of the cultivation are not dealt with due to ignorance about what will be the best future practices, e.g. crop residue management, the effect of crop rotation, changes in soil incorporation methods, changes in timing of present and novel management practices as well as the indirect effect of climate change on feed composition, quality of manure and irrigation needs. Water resource constraints shape the potential for irrigation as an adaptation measure to climate change, calling for the development of irrigation infrastructures. This option has already been discussed under Finnish (Peltonen-Sainio et al., 2015) and Swiss (Tendall and Gaillard, 2015) conditions, but should be considered at policy level also for Danish spring barley cultivation. Further efforts should be put in comparing different uses of straw, e.g. for energy, fodder or bedding, as well as the effects of slurry management options (ten Hoeve et $a l ., 2014)$ and integrated pest management (Juroszek and von Tiedemann, 2011), the beneficial effects of precision farming (Srinivasan, 2006) as well as the influence of climate change on soil organic C (Heikkinen et al., 2013). The temperature increase is expected to influence soil carbon degradation, as predicted with e.g. a 5\% reduction of $\mathrm{C}$ sequestration for soybean in case of a $2^{\circ} \mathrm{C}$ temperature increase (Petersen et al., 2013). The increase of organic matter mineralization could affect impact categories, such as CC and LU (Hörtenhuber et al., 2014; Petersen et al., 2013). Furthermore, we assumed that the proportion between yield in 
the ambient and the future climate scenarios in RERAF will also apply to the present versus future field conditions, but this may not be the case.

This LCA was performed considering Danish conditions, e.g. for fertilizer rates, soil types, fertilizer types, but the LCA results obtained may be used as a proxy to represent the situation for areas with same or similar crop management and environmental conditions, e.g. according to the classification of environmental zones by Trnka et al. (2011). The modeling of mineral fertilizer was performed assuming single nutrient fertilizer application, therefore excluding the application of K. K contribution to eutrophication is currently not taken into account in the ILCD recommended LCIA (Struijs et al., 2013), since the increase in algal growth in freshwater or marine systems accompanying the enrichment in nutrients is considered to be limited by $\mathrm{N}$ or $\mathrm{P}$ and $\mathrm{K}$ hence not considered relevant as contributor to this impact category. Regarding the calculation of P leaching we followed the approach by Nielsen and Wenzel (2007), also adopted by Hamelin et al. (2012), which calculates the surplus application as the difference between average $\mathrm{P}$ from manure application and average plant uptake of $\mathrm{P}$. Other approaches can be used for estimating P losses in LCA, see the Supporting Information (Appendix 6) in Hamelin et al. (2012) for a detailed list, as well as Smil (2000) and Maguire and Sims (2002) for a detailed description of P fluxes in agriculture and P leaching calculation, respectively.

Data availability represents a constraint in cereal LCA (Renzulli et al., 2015), where specific environmental input are needed, e.g. on soil type, and rainfall index. However, the use of specific conditions and assumptions valid at local level is not always an option, but proved to be significant for diesel fuel consumption from field operations; see e.g. Bacenetti et al. (2015) with regard to different technical solutions for seedbed preparation. 


\section{Conclusions}

In this study an LCA including primary data from experiments mimicking future worst case climate scenarios $\left(700 \mathrm{ppm}\left[\mathrm{CO}_{2}\right]\right.$ and $\left.+5^{\circ} \mathrm{C}\right)$ was performed. Results showed that these changed climatic conditions will likely increase the negative impacts on the environment from Danish spring barley cultivation. All environmental impact categories experienced indeed increased impact for all investigated scenarios, except under the very optimistic assumption that the pace of yield improvement by breeding will be the same as it was in the last decades. The main driver of the increased environmental impact was identified as the reduction in crop yield. Therefore, potential adaptation strategies should mainly focus on maintaining or improving crop productivity.

Our LCA results proved that the selection of proper cultivars is one effective way of reducing the environmental impacts of spring barley in the future, both with unchanged and varied fertilizer application rate. Furthermore, our results pointed out the consequence of the extreme weather events, since the gain in terms of crop yield obtained from breeding of the best yielding cultivars can be annulled by the effect of extreme events such as a long heat wave. The negative effect of extreme events on the increase of potential environmental impacts emphasizes the need to put more efforts in the development of cultivars with high yield and stability and resilience over a range of different environments.

Crop productivity is only one of the relevant aspects in the assessment of the performance of agricultural systems; crop quality is potentially just as important due to its implications for the product quality and diet. If yield measurements are based on relative crude protein content, considered as an indication of crop quality, the negative effects of the future climate seem to be reduced, and some scenarios showed lower impacts in the future compared to today. The reason is that crude protein, contrary to yield, is increased because the protein content of the cultivars tends to increase under the changed climate conditions. However, crude protein is common denomination for numerous proteins, which may or may not be beneficial in increased amounts, depending on the use of spring barley. 
Acknowledgements: The authors would like to thank the Nordic Council of Ministers

(NordForsk) for funding the project 'Sustainable production in a changing climate', as well as all project partners, in particular Rasmus Lund Hjortshøj, Jens Due Jensen and Lars Reitan for the profitable discussions. Furthermore, we would like to thank Teunis Dijkman for providing an updated version of PestLCI 2.0. Also the CORE ORGANIC II network COBRA contributed to this research making the $\mathrm{CP}$ analysis possible. 


\section{References:}

Bacenetti, J., Fusi, A., Negri, M., Fiala, M., 2015. Impact of cropping system and soil tillage on environmental performance of cereal silage productions. J. Clean. Prod. 86, 49-59. doi:10.1016/j.jclepro.2014.08.052

Brentrup, F., Küsters, J., Kuhlmann, H., Lammel, J., 2004. Environmental impact assessment of agricultural production systems using the life cycle assessment methodology I.

Theoretical concept of a LCA method tailored to crop production. Eur. J. Agron. 20, 247-264. doi:10.1016/S1161-0301(03)00024-8

Brisson, N., Gate, P., Gouache, D., Charmet, G., Oury, F.-X., Huard, F., 2010. Why are wheat yields stagnating in Europe? A comprehensive data analysis for France. F. Crop. Res. 119, 201-212. doi:10.1016/j.fcr.2010.07.012

Chirinda, N., Carter, M.S., Albert, K.R., Ambus, P., Olesen, J.E., Porter, J.R., Petersen, S.O., 2010. Emissions of nitrous oxide from arable organic and conventional cropping systems on two soil types. Agric. Ecosyst. Environ. 136, 199-208.

doi:10.1016/j.agee.2009.11.012

Collins, M., Knutti, R., Arblaster, J., Dufresne, J.-L., Fichefet, T., Friedlingstein, P., Gao, X., Gutowski, W., Johns, T., Krinner, G., Shongwe M, Tebaldi C, Weaver AJ, W.M., 2013. Long-term Climate Change: Projections, Commitments and Irreversibility. In Climate Change 2013: The Physical Science Basis. Contribution of Working Group I to the Fifth Assessment Report of the Intergovernmental Panel on Climate Change. Cambridge University Press, Cambridge, United Kingdom and New York, NY, USA,1535 pp.

Dalgaard, T., Halberg, N., Porter, J.R., 2001. A model for fossil energy use in Danish agriculture used to compare organic and conventional farming. Agric. Ecosyst. Environ. 87, 51-65. doi:10.1016/S0167-8809(00)00297-8

Dalgaard, T., Olesen, J.E., Petersen, S.O., Petersen, B.M., Jørgensen, U., Kristensen, T., Hutchings, N.J., Gyldenkærne, S., Hermansen, J.E., 2011. Developments in greenhouse gas emissions and net energy use in Danish agriculture e How to achieve substantial CO 2 reductions ? Environ. Pollut. 159, 3193-3203. doi:10.1016/j.envpol.2011.02.024

Danish Ministries of Food Agriculture and Fisheries, 2009. The Danish Plant Directorate. Vejledning om gødsknings- og harmoniregler. Planperioden 1.august 2008 til 31.juli 2009. Kgs. Lyngby, Denmark.

Danish Ministries of Food Agriculture and Fisheries, 2010. The Danish Plant Directorate. Vejledning om gødsknings- og harmoniregler. Planperioden 1.august 2009 til 31.juli 2010. Kgs. Lyngby, Denmark.

Danish Ministries of Food Agriculture and Fisheries, 2011. The Danish Plant Directorate. Vejledning om gødsknings- og harmoniregler. Planperioden 1.august 2010 til 31.juli 2011. Kgs. Lyngby, Denmark. 
Danish Ministries of Food Agriculture and Fisheries, 2012. The Danish Plant Directorate. Vejledning om gødsknings- og harmoniregler. Planperioden 1.august 2011 til 31.juli 2012. Copenahgen, Denmark.

Danish Ministries of Food Agriculture and Fisheries, 2013. The Danish Plant Directorate. Vejledning om gødsknings- og harmoniregler. Planperioden 1.august 2012 til 31.juli 2013. Copenahgen, Denmark.

DG Agriculture and Rural Development, U. for A.P.A. and P., 2013. Overview of CAP Reform 2014-2020.

Dijkman, T.J., 2013. Modelling of pesticide emissions for Life Cycle Inventory analysis: model develop- ment, applications and implications. PhD Thesis. Technical University of Denmark. Denmark.

Dijkman, T.J., Birkved, M., Hauschild, M.Z., 2012. PestLCI 2.0: a second generation model for estimating emissions of pesticides from arable land in LCA. Int. J. Life Cycle Assess. 17, 973-986. doi:10.1007/s11367-012-0439-2

Doltra, J., Lægdsmand, M., Olesen, J.E., 2012. Impacts of projected climate change on productivity and nitrogen leaching of crop rotations in arable and pig farming systems in Denmark. J. Agric. Sci. 152, 75-92. doi:10.1017/S0021859612000846

Dong, Y., Gandhi, N., Hauschild, M.Z., 2014. Development of Comparative Toxicity Potentials of 14 cationic metals in freshwater. Chemosphere 112, 26-33. doi:10.1016/j.chemosphere.2014.03.046

EC-JRC-IES, 2011. International Reference Life Cycle Data System (ILCD) HandbookRecommendations for Life Cycle Impact Assessment in the European context, First edit. ed. EUR 24571 EN. Publications Office of the European Union, Luxemburg. doi: $10.278 / 33030$

Edström, M., Pettersson, O., Nilsson, L., Hörndahl, T., 2005. Jordbrukssektorens energianvänding. JTI-rapport 342.

Estes, L.D., Beukes, H., Bradley, B. a, Debats, S.R., Oppenheimer, M., Ruane, A.C., Schulze, R., Tadross, M., 2013. Projected climate impacts to South African maize and wheat production in 2055: A comparison of empirical and mechanistic modeling approaches. Glob. Chang. Biol. 19, 3762-3774. doi:10.1111/gcb.12325

Fallahpour, F., Aminghafouri, a., Ghalegolab Behbahani, a., Bannayan, M., 2012. The environmental impact assessment of wheat and barley production by using life cycle assessment (LCA) methodology. Environ. Dev. Sustain. 14, 979-992. doi:10.1007/s10668-012-9367-3

Fedele, A., Mazzi, A., Niero, M., Zuliani, F., Scipioni, A., 2014. Can the LCA methodology be adopted to support a single farm on its environmental impacts forecast evaluation between conventional and organic production? An Italian case study. J. Clean. Prod. 69, 49-59. doi:10.1016/j.jclepro.2014.01.034 
Foley, J. a, Ramankutty, N., Brauman, K. a, Cassidy, E.S., Gerber, J.S., Johnston, M., Mueller, N.D., O’Connell, C., Ray, D.K., West, P.C., Balzer, C., Bennett, E.M., Carpenter, S.R., Hill, J., Monfreda, C., Polasky, S., Rockström, J., Sheehan, J., Siebert, S., Tilman, D., Zaks, D.P.M., 2011. Solutions for a cultivated planet. Nature 478, $337-$ 342. doi:10.1038/nature10452

Forster, P., Ramaswamy, V., Artaxo, P., Berntsen, T., Betts, R., Fahey, D.W., Haywood, J., Lean, J., Lowe, D.C., Myhre, G., Nganga, J., Prinn, R., Raga, G., M., S., Van Dorland, R., 2007. Changes in Atmospheric Constituents and in Radiative Forcing In: Climate Change 2007: The Physical Science Basis. Contribution of Working Group I to the Fourth Assessment Report of the Intergovernmental Panel on Climate Change. Cambridge University Press, Cambridge, United Kingdom and New York, NY, USA.

Frischknecht, R., Steiner, R., Jungbluth, N., 2008. Methode der ökologischen KnappheitÖkofaktoren 2006,. ö.b.u. und Bundesamt für Umwelt, Bern.

Greve, M., 2011. Jordbundsdata. Den landsomfattende jordklassificering.

Guinée, J., Gorrée, M., Heijungs, R., Huppes, G., Kleijn, R., de Koning, A., van Oers, L., Wegener Sleeswijk, A., Suh, S., Udo de Haes, H., de Bruijn, J., van Duin, R., Huijbregts, M., 2002. Handbook on life cycle assessment: operational guide to the ISO standards. Series: eco-efficiency in industry and science. Kluwer Academic Publishers, Dordrecht.

Hamelin, L., Jørgensen, U., Petersen, B.M., Olesen, J.E., Wenzel, H., 2012. Modelling the carbon and nitrogen balances of direct land use changes from energy crops in Denmark: a consequential life cycle inventory. GCB Bioenergy 4, 889-907. doi:10.1111/j.17571707.2012.01174.x

Hauschild, M.Z., Goedkoop, M., Guinée, J., Heijungs, R., Huijbregts, M., Jolliet, O., Margni, M., Schryver, A., Humbert, S., Laurent, A., Sala, S., Pant, R., 2013. Identifying best existing practice for characterization modeling in life cycle impact assessment. Int. J. Life Cycle Assess. 18, 683-697. doi:10.1007/s11367-012-0489-5

Hayashi, K., 2013. Practical recommendations for supporting agricultural decisions through life cycle assessment based on two alternative views of crop production: the example of organic conversion. Int. J. Life Cycle Assess. 18, 331-339. doi:10.1007/s11367-0120493-9

Heikkinen, J., Ketoja, E., Nuutinen, V., Regina, K., 2013. Declining trend of carbon in Finnish cropland soils in 1974-2009. Glob. Chang. Biol. 19, 1456-69. doi:10.1111/gcb.12137

Henriksen, H.J., Rosenbom, A., van der Keur, P., Olesen, J.E., Jørgensen, L.J., Kjær, J., Sonnenborg, T., Christensen, O.B., 2012. Prediction of climatic impacts on pesticide leaching to the aquatic environments. Pesticide research no. 143. Danish Ministry of the Environment. Environmental Protection Agency.

Högy, P., Poll, C., Marhan, S., Kandeler, E., Fangmeier, A., 2013. Impacts of temperature increase and change in precipitation pattern on crop yield and yield quality of barley. Food Chem. 136, 1470-7. doi:10.1016/j.foodchem.2012.09.056 
Hörtenhuber, S., Piringer, G., Zollitsch, W., Lindenthal, T., Winiwarter, W., 2014. Land use and land use change in agricultural life cycle assessments and carbon footprints - the case for regionally specific land use change versus other methods. J. Clean. Prod. 73, 31-39. doi:10.1016/j.jclepro.2013.12.027

Ingvordsen, C.H., 2014. Climate Change Effects to Plant Ecosystems - Resources for Future Barley Breeding. PhD thesis. Technical University of Denmark. Denmark.

Ingvordsen, C.H., Backes, G., Lyngkjær, M.F., Peltonen-Sainio, P., Jensen, J.D., Jalli, M., Jahoor, A., Rasmussen, M., Mikkelsen, T.N., Stockmarr, A., Jørgensen, R.B., 2015. Significant decrease in yield under future climate conditions: Stability and production of 138 spring barley accessions. Eur. J. Agron. 63, 105-113. doi:10.1016/j.eja.2014.12.003

IPCC, 2006. 2006 IPCC Guidelines for National Greenhouse Gas Inventories, Prepared by the National Greenhouse Gas Inventories Programme. IGES, Japan.

IPCC, 2007. Climate Change 2007: Impacts, Adaptation and Vulnerability. Contribution of Working Group II to the Fourth Assessment Report of the Intergovernmental Panel on Climate Change. Cambridge University Press, Cambridge, UK, 976pp.

ISO, 2006a. Environmental management. Life cycle assessment. Principle and framework. ISO 14040:2006. Geneva, Switzerland.

ISO, 2006b. Environmental management. Life cycle assessment. Requirements and guidelines. ISO 14044:2006. Geneva, Switzerland.

Jensen, N.H., Veihe, a., 2009. Modelling the effect of land use and climate change on the water balance and nitrate leaching in eastern Denmark. J. Land Use Sci. 4, 53-72. doi:10.1080/17474230802645832

Juroszek, P., von Tiedemann, a., 2011. Potential strategies and future requirements for plant disease management under a changing climate. Plant Pathol. 60, 100-112. doi:10.1111/j.1365-3059.2010.02410.x

Knowledge Centre for Agriculture, 2013. Dyrkningsvejledning for vårbyg. English title: Growing Instructions for spring barley. https://www.landbrugsinfo.dk (last accessed 24 Feb 2014).

Korsaeth, A., Henriksen, T.M., Roer, A.-G., Hammer Strømman, A., 2014. Effects of regional variation in climate and SOC decay on global warming potential and eutrophication attributable to cereal production in Norway. Agric. Syst. 127, 9-18. doi:10.1016/j.agsy.2013.12.007

Kristensen, K., Waagepetersen, J., Børgesen, C.D., Vinther, F.P., Grant, R., Blichermathiesen, G., 2008. Reestimation and further development in the model N-LES NLES3 to N-LES4. Aahrus, Denmark.

Leinonen, I., Williams, A.G., Waller, A.H., Kyriazakis, I., 2013. Comparing the environmental impacts of alternative protein crops in poultry diets: The consequences of uncertainty. Agric. Syst. 121, 33-42. doi:10.1016/j.agsy.2013.06.008 
Maguire, R.O., Sims, J.T., 2002. Soil Testing to Predict Phosphorus Leaching. J. Environ. Qual. 31, 1601-1609. doi:10.2134/jeq2002.1601

Martín, M.M.-S., Olesen, J.E., Porter, J.R., 2014. A genotype, environment and management (GxExM) analysis of adaptation in winter wheat to climate change in Denmark. Agric. For. Meteorol. 187, 1-13. doi:10.1016/j.agrformet.2013.11.009

Milà i Canals, L., Chenoweth, J., Chapagain, A., Orr, S., Antón, A., Clift, R., 2008. Assessing freshwater use impacts in LCA: Part I-inventory modelling and characterisation factors for the main impact pathways. Int. J. Life Cycle Assess. 14, 28-42. doi:10.1007/s11367008-0030-z

Milà, L., Bauer, C., Depestele, J., Dubreuil, A., Knuchel, R.F., 2007. Framework for LCIA of Land Use Land Use in LCA ( Subject Editor : Llorenç Milà i Canals ) Key Elements in a Framework for Land Use Impact Assessment Within LCA Land Use in LCA. Int. J. Life Cylce Assess. 12, 5-15.

Natur- og Landbrugskommissionens sekretariat, 2013. Natur og Landbrug - en ny start.

Nemecek, T., Dubois, D., Huguenin-Elie, O., Gaillard, G., 2011a. Life cycle assessment of Swiss farming systems: I. Integrated and organic farming. Agric. Syst. 104, 217-232. doi:10.1016/j.agsy.2010.10.002

Nemecek, T., Huguenin-Elie, O., Dubois, D., Gaillard, G., Schaller, B., Chervet, A., 2011b. Life cycle assessment of Swiss farming systems: II. Extensive and intensive production. Agric. Syst. 104, 233-245. doi:10.1016/j.agsy.2010.07.007

Nemecek, T., Kägi, T., 2007. Life Cycle Inventories of Agricultural Production Systems. ecoinvent report No. 15. Zürich and Dübendorf.

Newton, A.C., Johnson, S.N., Gregory, P.J., 2011. Implications of climate change for diseases, crop yields and food security. Euphytica 179, 3-18. doi:10.1007/s10681-0110359-4

Nielsen, O.-K., Plejdrup, M.S., Winther, M., Nielsen, M., Gyldenkærne, S., Mikkelsen, M.H., Albrektsen, R., Thomsen, M., Hjelgaard, K., Hoffmann, L., Fauser, P., Bruun, H.G., Johannsen, V.K., Nord-Larsen, T., Vesterdal, L., Møller, I.S., Caspersen, O.H., Rasmussen, E., Petersen, S.B., Baunbæk, L., Hansen, M.., 2013. Denmark's National Inventory Report 2013. Emission Inventories 1990-2011 - Submitted under the United Nations Framework Convention on Climate Change and the Kyoto Protocol.

Nielsen, P.H., Wenzel, H., 2007. Environmental Assessment of Ronozyme ® P5000 CT Phytase as an Alternative to Inorganic Phosphate Supplementation to Pig Feed Used in Intensive Pig Production. Int. J. Life Cylce Assess. 12, 514-520.

Notarnicola, B., Hayashi, K., Curran, M.A., Huisingh, D., 2012. Progress in working towards a more sustainable agri-food industry. J. Clean. Prod. 28, 1-8.

doi:10.1016/j.jclepro.2012.02.007 
Olander, L., Wollenberg, E., Tubiello, F., Herold, M., 2013. Advancing agricultural greenhouse gas quantification. Environ. Res. Lett. 8, 011002. doi:10.1088/17489326/8/1/011002

Olesen, J.E., Bindi, M., 2002. Consequences of climate change for European agricultural productivity, land use and policy. Eur. J. Agron. 16, 239-262. doi:10.1016/S11610301(02)00004-7

Olesen, J.E., Børgesen, C.D., Elsgaard, L., Palosuo, T., Rötter, R.P., Skjelvåg, a O., PeltonenSainio, P., Börjesson, T., Trnka, M., Ewert, F., Siebert, S., Brisson, N., Eitzinger, J., van Asselt, E.D., Oberforster, M., van der Fels-Klerx, H.J., 2012. Changes in time of sowing, flowering and maturity of cereals in Europe under climate change. Food Addit. Contam. Part A 29, 1527-42. doi:10.1080/19440049.2012.712060

Olesen, J.E., Rubæk, G.H., Heidmann, T., Hansen, S., D. Børgensen, C., 2004. Effect of climate change on greenhouse gas emissions from arable crop rotations. Nutr. Cycl. Agroecosystems 70, 147-160. doi:10.1023/B:FRES.0000048478.78669.33

Olesen, J.E., Trnka, M., Kersebaum, K.C., Skjelvåg, a. O., Seguin, B., Peltonen-Sainio, P., Rossi, F., Kozyra, J., Micale, F., 2011. Impacts and adaptation of European crop production systems to climate change. Eur. J. Agron. 34, 96-112. doi:10.1016/j.eja.2010.11.003

Peltonen-Sainio, P., Jauhiainen, L., Alakukku, L., 2015. Stakeholder perspectives for switching from rainfed to irrigated cropping systems at high latitudes. Land use policy 42, 586-593. doi:10.1016/j.landusepol.2014.09.019

Peltonen-Sainio, P., Jauhiainen, L., Laurila, I.P., 2009. Cereal yield trends in northern European conditions: Changes in yield potential and its realisation. F. Crop. Res. 110, 85-90. doi:10.1016/j.fcr.2008.07.007

Petersen, B.M., Knudsen, M.T., Hermansen, J.E., Halberg, N., 2013. An approach to include soil carbon changes in life cycle assessments. J. Clean. Prod. 52, 217-224. doi:10.1016/j.jclepro.2013.03.007

Pittelkow, C.M., Adviento-Borbe, M. a, van Kessel, C., Hill, J.E., Linquist, B. a, 2013. Optimizing rice yields while minimizing yield-scaled global warming potential. Glob. Chang. Biol. 20, 1382-1393. doi:10.1111/gcb.12413

Porter, J.R., Xie, L., Challinor, A., Cochrane, K., Howden, S., Iqbal, M., Lobell, D., Travasso, M., 2013. IPCC WGII AR5 Chapter 7. Food Security and Food Production Systems.

Posch, M., Seppälä, J., Hettelingh, J.-P., Johansson, M., Margni, M., Jolliet, O., 2008. The role of atmospheric dispersion models and ecosystem sensitivity in the determination of characterisation factors for acidifying and eutrophying emissions in LCIA. Int. J. Life Cycle Assess. 13, 477-486. doi:10.1007/s11367-008-0025-9

Poulsen, H.D., 2009. Normtal for husdyrgødning 2009. Aahrus, Denmark.

Poulsen, H.D., 2010. Normtal for husdyrgødning - 2010. Aahrus, Denmark. 
Poulsen, H.D., 2012a. Normtal for husdyrgødning - 2011. Aahrus, Denmark.

Poulsen, H.D., 2012b. Normtal for husdyrgødning -2012. Aahrus, Denmark.

Poulsen, H.D., 2013. Normtal for husdyrgødning -2013. Aahrus, Denmark.

Reap, J., Roman, F., Duncan, S., Bras, B., 2008. A survey of unresolved problems in life cycle assessment. Int. J. Life Cycle Assess. 13, 290-300. doi:10.1007/s11367-008-0008$\mathrm{x}$

Renzulli, P.A., Bacenetti, J., Graziella, B., Fusi, A., Ioppolo, G., Niero, M., Proto, M., Salomone, R., Sica, D., Supino, S., 2015. Life Cycle Assessment in the Cereal and Derived Products Sector, in: Notarnicola, B., Salomone, R., Petti, L., Renzulli, P.A., Roma, R., Cerrutti, A.K. (Eds.), Life Cycle Assessment in the Agri-Food Sector. Case Studies, Methodological Issues and Best Practices. Springer, pp. 185-250.

Roer, A.-G., Korsaeth, A., Henriksen, T.M., Michelsen, O., Strømman, A.H., 2012. The influence of system boundaries on life cycle assessment of grain production in central southeast Norway. Agric. Syst. 111, 75-84. doi:10.1016/j.agsy.2012.05.007

Rosenbaum, R.K., Bachmann, T.M., Gold, L.S., Huijbregts, M. a. J., Jolliet, O., Juraske, R., Koehler, A., Larsen, H.F., MacLeod, M., Margni, M., McKone, T.E., Payet, J., Schuhmacher, M., Meent, D., Hauschild, M.Z., 2008. USEtox - the UNEP-SETAC toxicity model: recommended characterisation factors for human toxicity and freshwater ecotoxicity in life cycle impact assessment. Int. J. Life Cycle Assess. 13, 532-546. doi:10.1007/s11367-008-0038-4

Rötter, R.P., Palosuo, T., Pirttioja, N.K., Dubrovsky, M., Salo, T., Fronzek, S., Aikasalo, R., Trnka, M., Ristolainen, A., Carter, T.R., 2011. What would happen to barley production in Finland if global warming exceeded $4^{\circ} \mathrm{C}$ ? A model-based assessment. Eur. J. Agron. 35, 205-214. doi:10.1016/j.eja.2011.06.003

Röös, E., Sundberg, C., Hansson, P.-A., 2011. Uncertainties in the carbon footprint of refined wheat products: a case study on Swedish pasta. Int. J. Life Cycle Assess. 16, 338-350. doi:10.1007/s11367-011-0270-1

Schillinger, W.F., 2005. Tillage Method and Sowing Rate Relations for Dryland Spring Wheat, Barley, and Oat. Crop Sci. 45, 2636. doi:10.2135/cropsci2005.04-0016

Smil, V., 2000. Phosphorus in the environment: Natural Flows and Human Interferences. Annu. Energy Environ. 25, 53-88.

Smith, W.N., Grant, B.B., Desjardins, R.L., Kroebel, R., Li, C., Qian, B., Worth, D.E., McConkey, B.G., Drury, C.F., 2013. Assessing the effects of climate change on crop production and GHG emissions in Canada. Agric. Ecosyst. Environ. 179, 139-150. doi:10.1016/j.agee.2013.08.015

Snyder, C.S., Bruulsema, T.W., Jensen, T.L., Fixen, P.E., 2009. Review of greenhouse gas emissions from crop production systems and fertilizer management effects. Agric. Ecosyst. Environ. 133, 247-266. doi:10.1016/j.agee.2009.04.021 
Srinivasan, A., 2006. Handbook of precision agriculture: principles and applications. Haworth Press, New York, USA.

Statistics Denmark, 2014a. AFG1: Crops by crop, unit and area [WWW Document]. URL www.dst.dk (accessed 2.24.14).

Statistics Denmark, 2014b. KOMB07: Livestock combination with cattle and pigs by region, type and unit. [WWW Document]. URL www.statbank.dk/KOMB07 (accessed 2.24.14).

Statistics Denmark, 2014c. HALM1: Straw yield and use by region, crop, unit and use [WWW Document]. URL www.dst.dk (accessed 2.24.14).

Stoumann, L., Schjoerring, J.K., Hoek, K.W. Van Der, Poulsen, H.D., Zevenbergen, J.F., Pallière, C., Lammel, J., Brentrup, F., Jongbloed, A.W., Willems, J., Grinsven, H. Van, Jensen, L.S., 2011. Benefits of nitrogen for food, fibre and industrial production, in: Sutton, M.A., Howard, C.M., Erisman, J.W., Billen, B., Bleeker, A., Grennfelt, P., H, van G., Grizzetti, B. (Eds.), . Cambridge University Press., pp. 32-61.

Struijs, J., Beusen, A., van Jaarsveld, H., Huijbregts, M.A.J., 2013. Chapter 6: Eutrophication. In: Goedkoop M., Heijungs R., Huijbregts M., De Schryver A., Struijs J., van Zelm, R. A life cycle impact assessment method which comprises harmonised category indicators at the midpoint and the endpoint level. First edition (ve.

Sutter, J., 2010. Life cycle inventories of pesticides. St. Gallen, Switzerland.

Ten Hoeve, M., Hutchings, N.J., Peters, G.M., Svanström, M., Jensen, L.S., Bruun, S., 2014. Life cycle assessment of pig slurry treatment technologies for nutrient redistribution in Denmark. J. Environ. Manage. 132, 60-70. doi:10.1016/j.jenvman.2013.10.023

Tendall, D.M., Gaillard, G., 2015. Environmental consequences of adaptation to climate change in Swiss agriculture: An analysis at farm level. Agric. Syst. 132, 40-51. doi:10.1016/j.agsy.2014.09.006

Tester, M., Langridge, P., 2010. Breeding technologies to increase crop production in a changing world. Science 327, 818-22. doi:10.1126/science.1183700

Trnka, M., Olesen, J.E., Kersebaum, K.C., Skjelvåg, a. O., Eitzinger, J., Seguin, B., PeltonenSainio, P., Rötter, R., Iglesias, A., Orlandini, S., Dubrovský, M., Hlavinka, P., Balek, J., Eckersten, H., Cloppet, E., Calanca, P., Gobin, a., Vučetić, V., Nejedlik, P., Kumar, S., Lalic, B., Mestre, a., Rossi, F., Kozyra, J., Alexandrov, V., Semerádová, D., Žalud, Z., 2011. Agroclimatic conditions in Europe under climate change. Glob. Chang. Biol. 17, 2298-2318. doi:10.1111/j.1365-2486.2011.02396.x

White, J.W., Hoogenboom, G., Kimball, B. a., Wall, G.W., 2011. Methodologies for simulating impacts of climate change on crop production. F. Crop. Res. 124, 357-368. doi:10.1016/j.fcr.2011.07.001 


\section{Highlights:}

- Climate change effects on spring barley cultivation in Denmark quantified by LCA

- Simultaneously elevated $\mathrm{CO}_{2}$ and $\mathrm{T} \pm$ heat wave: influence on crop yield and quality

- We used primary data from experiments mimicking future climate scenarios

- Main driver of increased impacts is the change in crop yield

- Potential adaptation strategies should aim at breeding for more resilient cultivars 


\section{Figure captions}

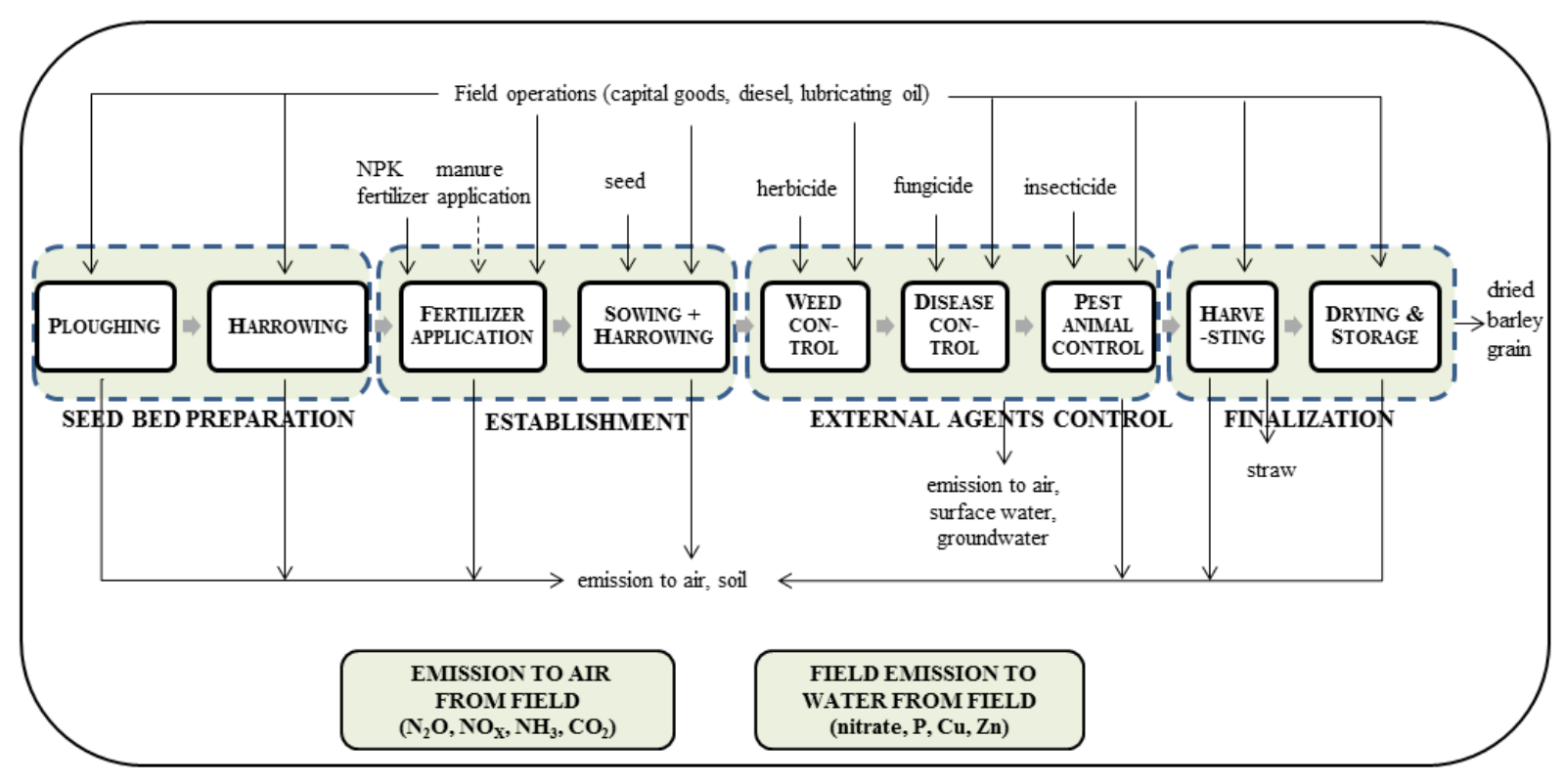

Figure 1 - Spring barley product system boundaries with indication of the main input and output and the sequence of the field work processes. Dashed lines represent the four main steps of the field work related processes, named with capital letters. The production of NPK fertilizer, seed, herbicide, fungicide and insecticide is also included. 


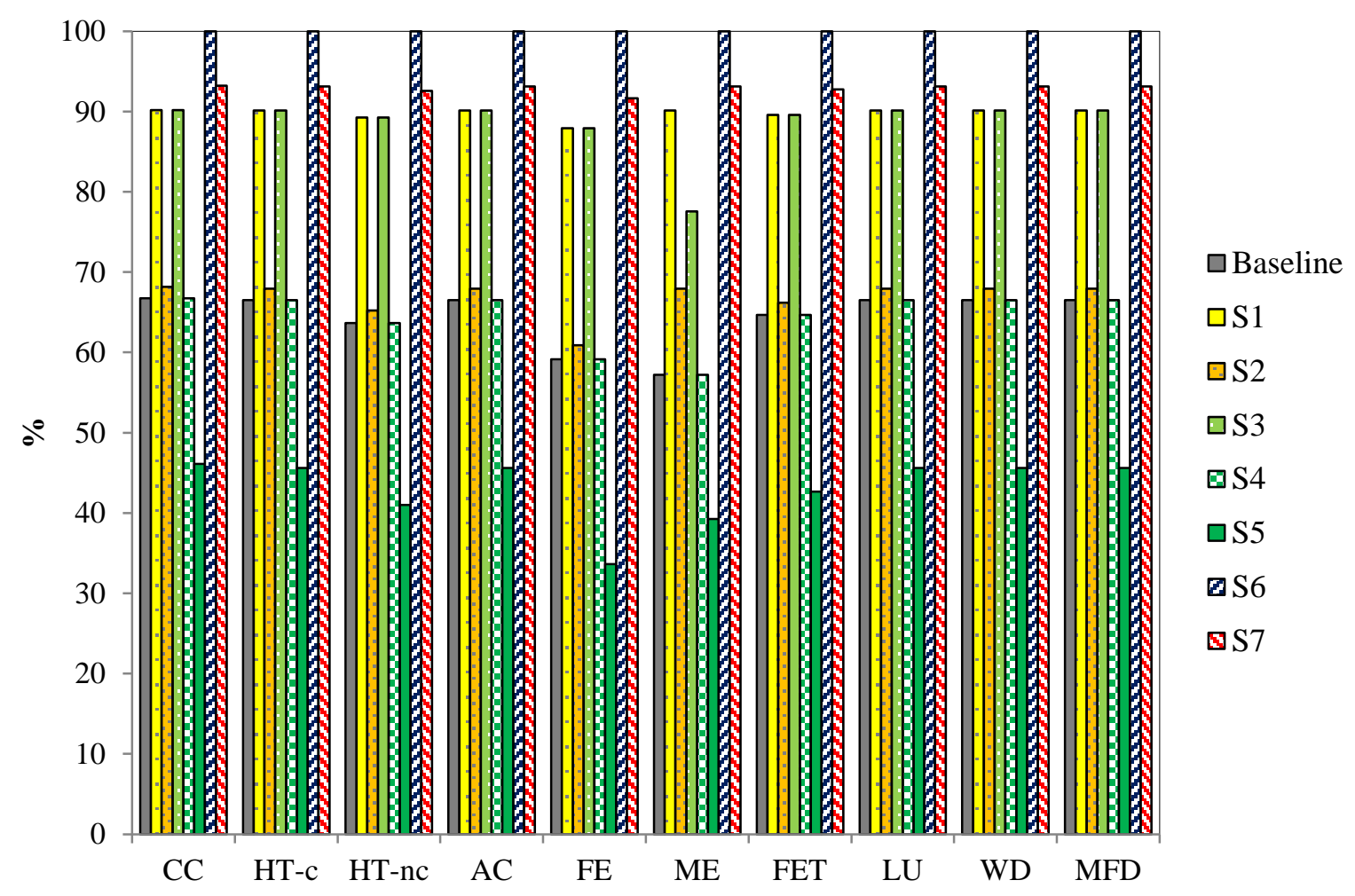

Figure 2 LCIA results for the eight scenarios (baseline and S1-S7) in the form of characterized impact profiles showing the scores in relative terms for the impact categories included in the study, i.e. climate change (CC), human toxicity due to carcinogens (HT-c) and non carcinogens (HT-nc), acidification (AC), freshwater eutrophication (FE), marine eutrophication (ME), freshwater ecotoxicity (FET), land use (LU), water depletion (WD), mineral \& fossil depletion (MFD). 


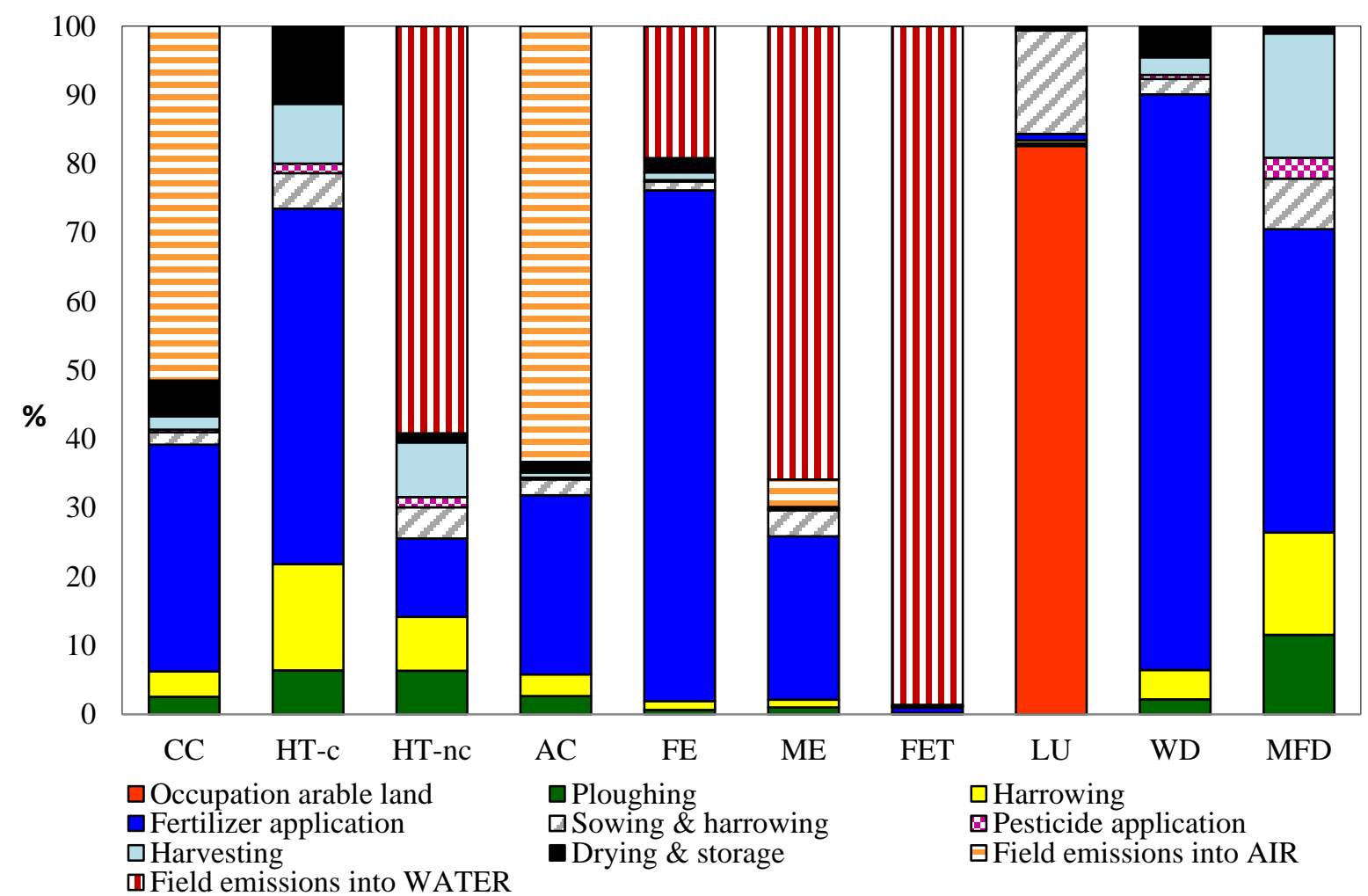

Figure 3 Contribution analysis of the unit processes for current spring barley production in Denmark (baseline scenario) for the impact categories included in the study, i.e. climate change (CC), human toxicity due to carcinogens (HT-c) and non carcinogens (HT-nc), acidification (AC), freshwater eutrophication (FE), marine eutrophication (ME), freshwater ecotoxicity (FET), land use (LU), water depletion (WD), mineral \& fossil depletion (MFD). 
Niero et al. (2015) Agricultural Systems 136, 46-60

http://dx.doi.org/10.1016/j.agsy.2015.02.007

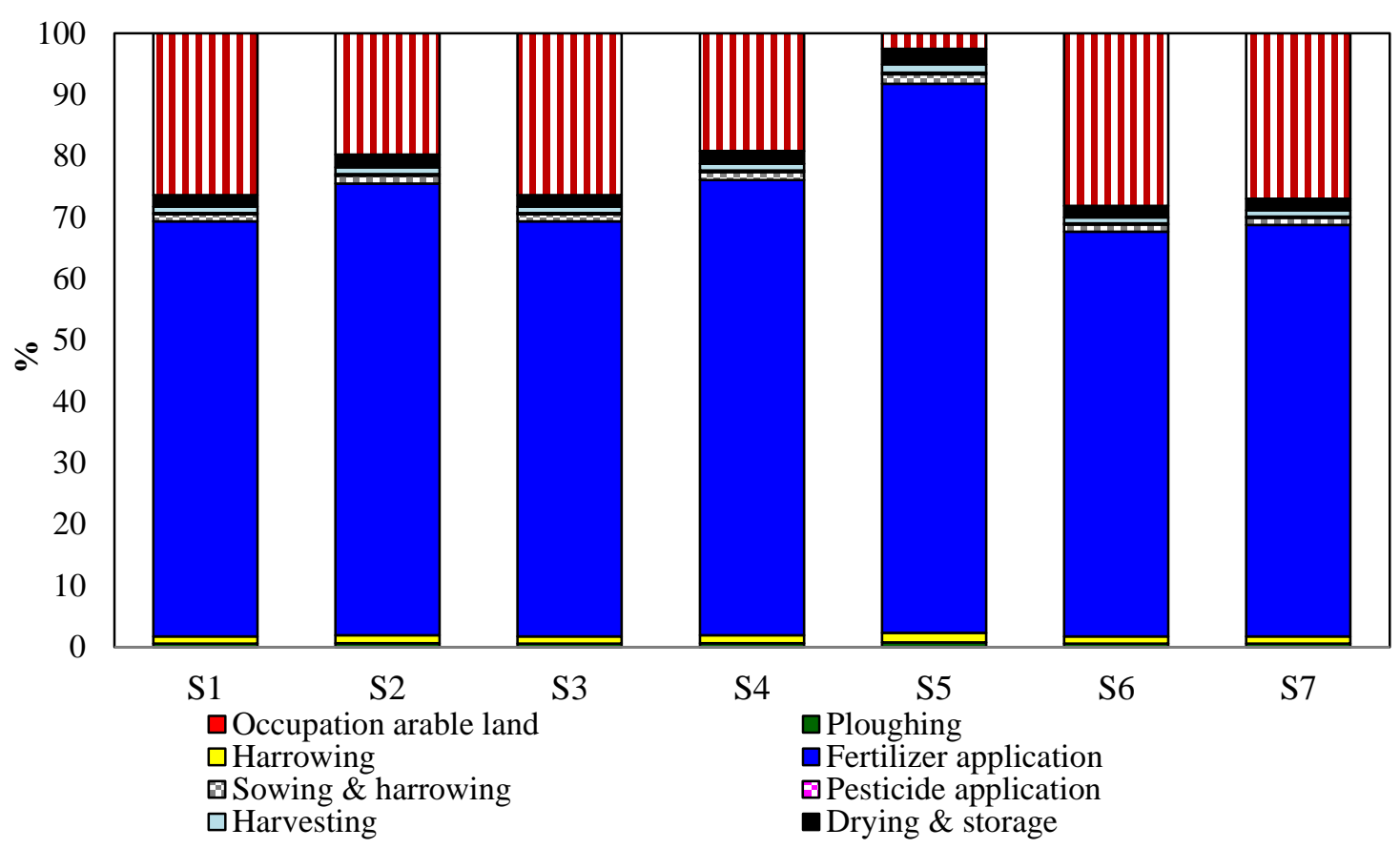

Figure 4 Contribution analysis of the unit processes for the alternative future scenarios with regard to the impact category freshwater eutrophication (FE). 


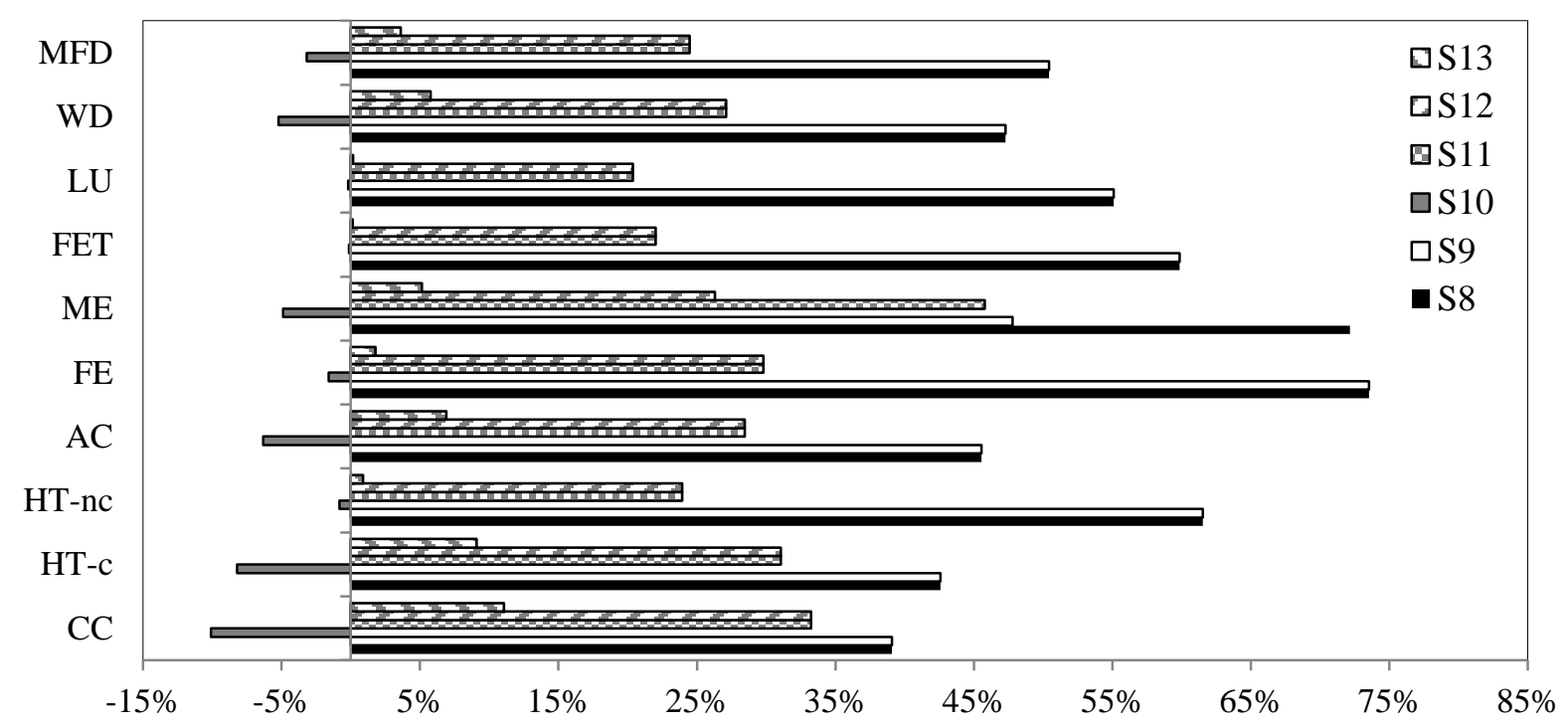

Figure 5 Deviations in \% from the impacts of the current spring barley production for the additional alternative future scenarios considering a decrease of $\mathrm{N}$ fertilizer application (S8, $\mathrm{S} 9, \mathrm{~S} 10)$ and an increase of $\mathrm{N}$ fertilizer application (S11, S12, S13) for the impact categories included in the study, i.e. climate change (CC), human toxicity due to carcinogens (HT-c) and non carcinogens (HT-nc), acidification (AC), freshwater eutrophication (FE), marine eutrophication (ME), freshwater ecotoxicity (FET), land use (LU), water depletion (WD), mineral \& fossil depletion (MFD). 
Table 1 Life cycle inventory flows for the unit processes included in the LCI modelling

referred to 1 ha, including sources and main adjustments considered in the study. Names in

italics refer to the ecoinvent process used.

\begin{tabular}{|c|c|c|c|c|}
\hline $\begin{array}{l}\text { Unit } \\
\text { process }\end{array}$ & Inventory flow & Value & Unit & Source of data and main adjustments \\
\hline $\begin{array}{l}\text { Barley } \\
\text { cultivation }\end{array}$ & Arable land occupation & $1.49 \mathrm{E}-4$ & ha & $\begin{array}{l}\text { Given by the inverse of average crop yield for spring } \\
\text { barley in loamy sand soil in the 5-years interval from } \\
2009-2013 \text { with } 85 \% \text { DM content }\end{array}$ \\
\hline \multirow{2}{*}{ Ploughing } & $\begin{array}{l}\text { Ploughing - operations on } \\
\text { the field }\end{array}$ & 1 & ha & $\begin{array}{l}\text { Tillage, ploughing/CH } U \text { adapted with Danish diesel } \\
\text { consumption }(19.32 \mathrm{~kg} / \mathrm{ha}) \text { and emissions into air from } \\
\text { diesel }\end{array}$ \\
\hline & Lubrication oil & $1.20 \mathrm{E}-2$ & $\mathrm{~kg} / \mathrm{ha}$ & $\begin{array}{l}\text { Lubricating oil, at plant/RER } U \text { adapted with Danish } \\
\text { energy mix and diesel consumption and emissions into } \\
\text { air from diesel }\end{array}$ \\
\hline \multirow{4}{*}{ Harrowing } & Harrowing by rotary harrow & 1 & ha & Tillage, harrowing, by rotary harrow/CHU \\
\hline & Seedbed harrowing & 1 & ha & $\begin{array}{l}\text { Tillage, harrowing, by rotary harrow/CH } U \text { adapted } \\
\text { with Danish diesel consumption }(5.04 \mathrm{~kg} / \mathrm{ha} \text { ) and } \\
\text { emissions into air from diesel }\end{array}$ \\
\hline & Stubble harrowing & 1 & ha & $\begin{array}{l}\text { Mulching/CH } U \text { adapted with Danish diesel } \\
\text { consumption }(5.88 \mathrm{~kg} / \mathrm{ha} \text { ) and emissions into air from } \\
\text { diesel, based on Hamelin et al. (2012) }\end{array}$ \\
\hline & Lubrication oil & $9.10 \mathrm{E}-2$ & $\mathrm{~kg}$ & $\begin{array}{l}\text { Lubricating oil, at plant/RER } U \text { adapted with Danish } \\
\text { energy mix and diesel consumption and emissions into } \\
\text { air from diesel }\end{array}$ \\
\hline \multirow{9}{*}{$\begin{array}{l}\text { Fertilizer } \\
\text { application }\end{array}$} & Fertilizing by broadcasting & 1 & ha & $\begin{array}{l}\text { Fertilising, by broadcaster/CH U adapted with Danish } \\
\text { diesel consumption }(1.68 \mathrm{~kg} / \mathrm{ha}) \text { and emissions into air } \\
\text { from diesel }\end{array}$ \\
\hline & Slurry spreading & 23.74 & $\mathrm{~m}^{3}$ & $\begin{array}{l}\text { Slurry spreading, by vacuum tanker/CH adapted with } \\
\text { Danish electricity mix in diesel production and based on } \\
\text { application of } 25 \text { ton manure/ha }\end{array}$ \\
\hline & Lubrication oil & $1.37 \mathrm{E}-2$ & $\mathrm{~kg}$ & $\begin{array}{l}\text { Lubricating oil, at plant/RER } U \text { adapted with Danish } \\
\text { energy mix and diesel consumption and emissions into } \\
\text { air from diesel }\end{array}$ \\
\hline & $\begin{array}{l}\text { Mineral fertilizer }-\mathrm{N} \\
\text { component }\end{array}$ & 130 & $\mathrm{~kg}$ & $\begin{array}{l}\text { Calcium ammonium nitrate, as } N \text {, at regional } \\
\text { storehouse/RER } U \text { adjusted with } 0.0062 \mathrm{~kg} \mathrm{~N}_{2} \mathrm{O} / \mathrm{kg} \\
\text { nitric acid based on (Hamelin } \text { et al., 2012) }\end{array}$ \\
\hline & $\begin{array}{l}\text { Mineral fertilizer }-\mathrm{P} \\
\text { component }\end{array}$ & 81.4 & $\mathrm{~kg}$ & $\begin{array}{l}\text { Single superphosphate, as } \mathrm{P} 2 \mathrm{O} 5 \text {, at regional } \\
\text { storehouse/RER } U\end{array}$ \\
\hline & $\begin{array}{l}\text { Manure, applied - N } \\
\text { component }\end{array}$ & 78 & $\mathrm{~kg}$ & $\begin{array}{l}\text { Given by the sum of } \mathrm{N} \text { content in pig slurry }(34,06 \mathrm{~kg} \\
\mathrm{N} / \mathrm{kg}) \text { and dairy cattle slurry }(43,91 \mathrm{~kg} \mathrm{~N} / \mathrm{kg})\end{array}$ \\
\hline & $\begin{array}{l}\text { Manure, applied - P } \\
\text { component }\end{array}$ & 15.7 & $\mathrm{~kg}$ & $\begin{array}{l}\text { Given by the sum of P content in pig slurry }(8,34 \mathrm{~kg} \\
\mathrm{P} / \mathrm{kg}) \text { and dairy cattle slurry }(7,34 \mathrm{~kg} \mathrm{P} / \mathrm{kg})\end{array}$ \\
\hline & $\begin{array}{l}\text { Fertilizer applied }-\mathrm{N} \\
\text { component }\end{array}$ & 35 & $\mathrm{~kg}$ & $\begin{array}{l}\text { Given by the difference between the required } \mathrm{N} \text { supply } \\
(113 \mathrm{~kg} \mathrm{~N} / \mathrm{ha} \text { ) and } \mathrm{N} \text { content from slurry }\end{array}$ \\
\hline & $\begin{array}{l}\text { Fertilizer, applied }-\mathrm{P} \\
\text { component }\end{array}$ & 6.32 & $\mathrm{~kg}$ & $\begin{array}{l}\text { Given by the difference between the required P supply } \\
(22 \mathrm{~kg} \mathrm{P} / \mathrm{ha}) \text { and } \mathrm{P} \text { content from slurry }\end{array}$ \\
\hline \multirow{3}{*}{$\begin{array}{l}\text { Sowing \& } \\
\text { harrowing }\end{array}$} & Sowing & 1 & ha & $\begin{array}{l}\text { Sowing/CH } U \text { adapted with Danish diesel consumption } \\
(2.52 \mathrm{~kg} / \mathrm{ha}) \text { and emissions into air from diesel }\end{array}$ \\
\hline & Lubrication oil & $4.60 \mathrm{E}-2$ & $\mathrm{~kg}$ & $\begin{array}{l}\text { Lubricating oil, at plant/RER } U \text { adapted with Danish } \\
\text { energy mix and diesel consumption and emissions into } \\
\text { air from diesel }\end{array}$ \\
\hline & Barley seed & 116 & $\mathrm{~kg}$ & $\begin{array}{l}\text { Barley seed IP, at regional storehouse/CH } U \\
\text { Sowing rate }(\mathrm{kg} / \mathrm{ha})=1000 \text { grain weight }(44 \mathrm{~g})^{\mathrm{a}} \mathrm{x} \\
\text { desired plants } / \mathrm{m}^{2}(250)^{\mathrm{b}} \div \text { germination percentage } \\
(95 \%)^{\mathrm{c}}\end{array}$ \\
\hline
\end{tabular}




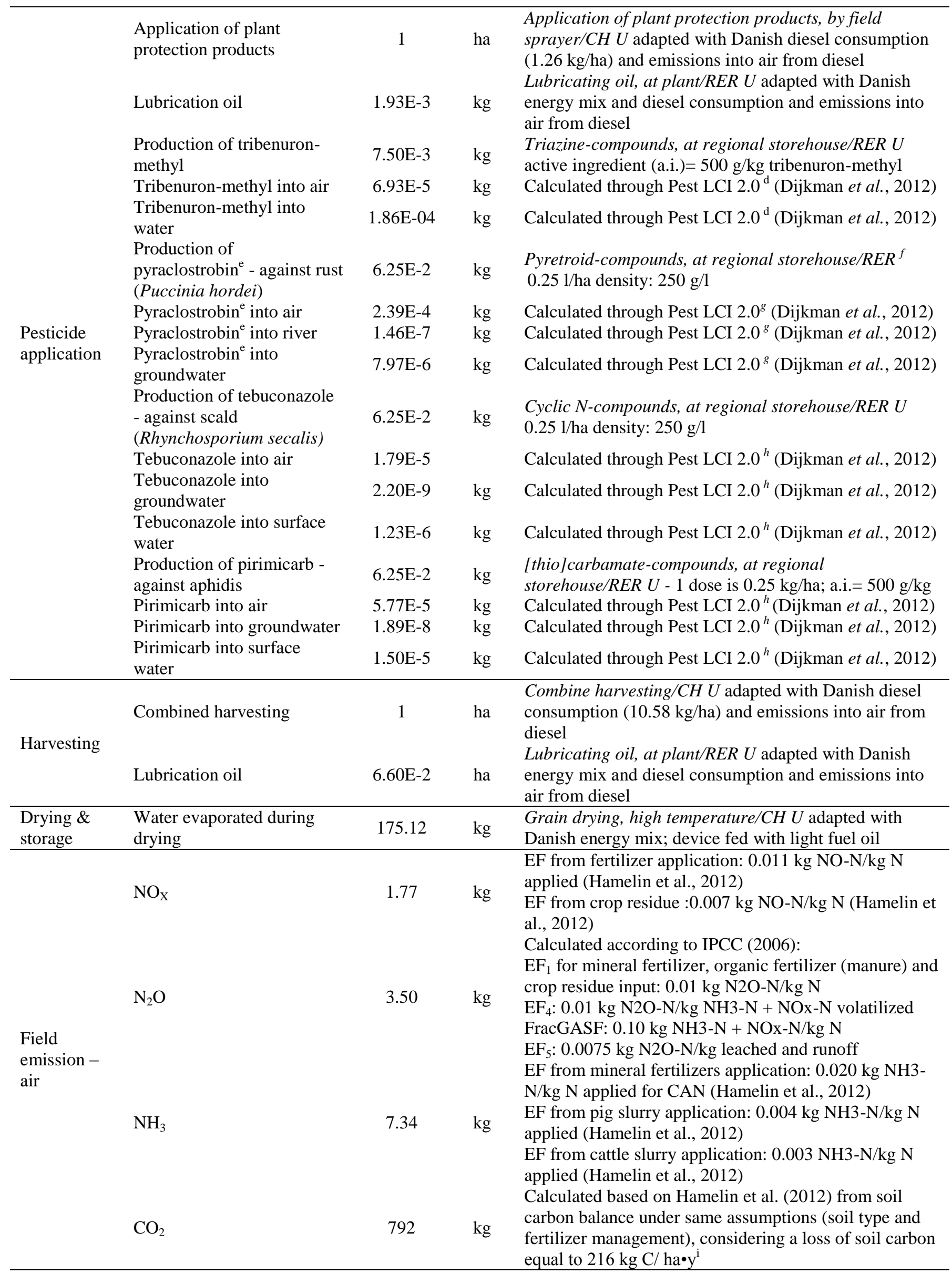


Niero et al. (2015) Agricultural Systems 136, 46-60

http://dx.doi.org/10.1016/j.agsy.2015.02.007

\begin{tabular}{|c|c|c|c|c|}
\hline \multirow{4}{*}{$\begin{array}{l}\text { Field } \\
\text { emission - } \\
\text { water }\end{array}$} & $\mathrm{NO}_{3}{ }^{-}$ & 126 & $\mathrm{~kg}$ & $\begin{array}{l}\text { Calculated using N-LES4 model (Kristensen et al., } \\
\text { 2008) }\end{array}$ \\
\hline & P, total & $3.73 \mathrm{E}-1$ & $\mathrm{~kg}$ & $\begin{array}{l}\text { Calculated as } 5 \% \text { of the net surplus application (Nielsen } \\
\& \text { Wenzel, 2007) }\end{array}$ \\
\hline & $\mathrm{Cu}$ & $2.87 \mathrm{E}-1$ & $\mathrm{~kg}$ & $\begin{array}{l}\text { Calculated considering that } 100 \% \text { of } \mathrm{Cu} \text { surplus is lost } \\
\text { (Hamelin et al. 2012) }\end{array}$ \\
\hline & $\mathrm{Zn}$ & $6.63 \mathrm{E}-1$ & $\mathrm{~kg}$ & $\begin{array}{l}\text { Calculated considering that } 100 \% \text { of } \mathrm{Zn} \text { surplus is lost } \\
\text { (Hamelin et al. 2012) }\end{array}$ \\
\hline
\end{tabular}

${ }^{1}$ based on https://www.landbrugsinfo.dk/planteavl/afgroeder/korn/vaarbyg/sider/pl_pn_10_041.aspx

${ }^{b}$ based on Bertholdsson \& Kolodinska Brantestam (2009)

${ }^{c}$ assumption

${ }^{d}$ crop type: cereals (leaf development); application month: April

${ }^{e}$ used as a proxy of picoxystrobin

${ }^{f}$ based on the assumption by Hamelin et al. (2012) - supplementary information Table S5 Appendix 2

${ }^{g}$ crop type: cereals (tillering); application month: May

${ }^{h}$ crop type: cereals (booting/senescence); application month: June

${ }^{i}$ which is released to the atmosphere as $\mathrm{CO}_{2}$ 
Table 2 Crop yield data in terms of average and standard deviation of the spring barley cultivars included in the experimental scenarios in RERAF climate phytotron

\begin{tabular}{|c|c|c|c|}
\hline \multirow[b]{2}{*}{ Type of cultivars } & \multicolumn{3}{|c|}{ Crop yield } \\
\hline & Ambient & $\begin{array}{l}\text { Double treatment } \\
\left(\uparrow \mathrm{T} \& \uparrow \mathrm{CO}_{2}\right)\end{array}$ & $\begin{array}{l}\text { Double treatment } \\
\text { \& heat-wave }\end{array}$ \\
\hline $\begin{array}{l}13 \text { cultivars } \\
\text { (Alf - Alliot - Anakin -Anita-Arve - Brage - } \\
\text { Brio - Drost Pajbjerg - Edvin-Evergreen - } \\
\text { Mari - Prestige - Sebastian) }\end{array}$ & $\begin{array}{l}103.86 \pm 15.54 \\
\mathrm{hkg} / \mathrm{ha}\end{array}$ & $\begin{array}{l}76.67 \pm 24.18 \\
\mathrm{hkg} / \mathrm{ha}\end{array}$ & $\begin{array}{l}48.00 \pm 11.73 \\
\mathrm{hkg} / \mathrm{ha}\end{array}$ \\
\hline $\begin{array}{l}5 \text { best crop yielding cultivars } \\
\text { (Alliot - Brage - Brio - Prestige - Sebastian) }\end{array}$ & $\begin{array}{l}104.81 \pm 7.73 \\
\mathrm{hkg} / \mathrm{ha}\end{array}$ & $\begin{array}{l}102.56 \pm 11.20 \\
\mathrm{hkg} / \mathrm{ha}\end{array}$ & $\begin{array}{l}60.15 \pm 11.62 \\
\mathrm{hkg} / \mathrm{ha}\end{array}$ \\
\hline
\end{tabular}


Table 3 Summary of the alternative scenarios applied for future spring barley cultivation, their main features, modelling assumptions and the relative difference from the current crop yield. The third column reports in brackets the \% difference from the value for the current baseline scenario, meanwhile the fourth column reports in brackets the standard deviation.

\begin{tabular}{|c|c|c|c|c|}
\hline Scenario & Main features & $\begin{array}{c}\text { Nitrate } \\
\text { leaching } \\
{\left[\mathrm{NO}_{3}^{-} / \mathrm{ha}\right]}\end{array}$ & $\begin{array}{l}\text { Crop yield } \\
\text { [kg/ha] }\end{array}$ & $\begin{array}{l}\text { \% crop yield } \\
\text { difference }\end{array}$ \\
\hline $\mathrm{S} 1$ & No adaptation - All cultivars & $\begin{array}{c}157 \\
(+24 \%)\end{array}$ & $\begin{array}{c}4207 \\
( \pm 13.3)\end{array}$ & $-26.2 \%{ }^{a}$ \\
\hline S2 & No adaptation - Best 5 yielding cultivars & $\begin{array}{c}157 \\
(+24 \%)\end{array}$ & $\begin{array}{l}5580 \\
( \pm 6.1)\end{array}$ & $-2.1 \%^{\mathrm{a}}$ \\
\hline S3 & Adaptation - Early sowing & $\begin{array}{l}126 \\
(0 \%)\end{array}$ & $\begin{array}{c}4207 \\
( \pm 13.3)\end{array}$ & $-26.2 \%^{\mathrm{a}}$ \\
\hline S4 & $\begin{array}{l}\text { Adaptation - Improved cultivars with same } \\
\text { crop yield as today }\end{array}$ & $\begin{array}{l}126 \\
(0 \%)\end{array}$ & $\begin{array}{c}5700 \\
( \pm 0.6)^{b}\end{array}$ & $0 \%$ \\
\hline S5 & $\begin{array}{l}\text { Adaptation - Improved cultivars with better } \\
\text { crop yield than today }\end{array}$ & $\begin{array}{l}126 \\
(0 \%)\end{array}$ & $\begin{array}{c}9612 \\
(9120-10830)\end{array}$ & $+68.6 \%$ \\
\hline S6 & Extreme event - all cultivars & $\begin{array}{c}157 \\
(+24 \%)\end{array}$ & $\begin{array}{c}3791 \\
( \pm 11.7)\end{array}$ & $-33.5 \%^{\mathrm{c}}$ \\
\hline S7 & Extreme event - best 5 yielding cultivars & $\begin{array}{c}157 \\
(+24 \%) \\
\end{array}$ & $\begin{array}{c}4070 \\
( \pm 11.6)\end{array}$ & $-28.6 \%^{\mathrm{c}}$ \\
\hline
\end{tabular}

${ }^{\mathrm{a}} \%$ difference between ambient and double treatment, as reported in Table 2

${ }^{\mathrm{b}}$ calculated from 5-yrs interval based on (Danish Ministries of Food Agriculture and Fisheries, 2009 - 2013)

${ }^{\mathrm{c}} \%$ difference between double treatment without and with and heat-wave; since data refer to a different

experiments, double treatment data used as reference were slightly different from those reported in Table 2 
Table 4 Summary of the scenarios considered in the sensitivity analysis on $\mathrm{N}$ fertilizer applied, their main features, modelling assumptions and the relative difference with the current crop yield.

\begin{tabular}{llccc}
\hline Scenario & Main features & $\begin{array}{c}\text { N fertilizer } \\
\text { applied } \\
\text { [kg N/ha] }\end{array}$ & $\begin{array}{c}\text { Nitrate } \\
\text { leaching } \\
{\left[\text { NO }_{3}^{-} \text {/ha] }\right.}\end{array}$ & $\begin{array}{c}\text { \% crop yield } \\
\text { difference from } \\
\text { current }\end{array}$ \\
\hline S8 & $\begin{array}{l}\text { No adaptation - all cultivars } \\
-10 \% \text { N fertilizer }\end{array}$ & 102 & 152 & $-35.6 \%$ \\
S9 & $\begin{array}{l}\text { Adaptation - early sowing } \\
-10 \% \text { N fertilizer }\end{array}$ & 102 & 122 & $-35.6 \%$ \\
S10 & $\begin{array}{l}\text { Adaptation - improved cultivars with same } \\
\text { crop yield as today } \\
-10 \% \text { N fertilizer } \\
\text { No adaptation - all cultivars }\end{array}$ & 102 & 122 & 0 \\
S11 & $\begin{array}{l}\text { +10\% N fertilizer } \\
\text { Adaptation - early sowing } \\
\text { +10\% N fertilizer } \\
\text { Adaptation - improved cultivars with same } \\
\text { crop yield as today } \\
+10 \% \text { N fertilizer }\end{array}$ & 125 & 161 & $-16.8 \%$ \\
S13 & 125 & 130 & $-16.8 \%$ \\
\hline
\end{tabular}


Table 5 Life Cycle Impact Assessment results calculated for the current spring barley production (baseline) and seven alternative future scenarios (S1-S7) in absolute terms and including the deviation from current sprig barley production, referred to $1 \mathrm{~kg}$ DM spring barley grain as functional unit.

\begin{tabular}{|c|c|c|c|c|c|c|c|c|c|}
\hline $\begin{array}{l}\text { Impact } \\
\text { category }\end{array}$ & Units & Baseline & S1 & $\mathbf{S 2}$ & $\mathbf{S 3}$ & S4 & S5 & S6 & S7 \\
\hline \multirow{2}{*}{$\begin{array}{l}\text { Climate change } \\
\text { (CC) }\end{array}$} & $\begin{array}{c}\mathrm{kg} \mathrm{CO} \\
\text { eq }\end{array}$ & 5.32E-01 & 7.19E-01 & $5.43 \mathrm{E}-01$ & 7.19E-01 & 5.32E-01 & $3.68 \mathrm{E}-01$ & $7.97 \mathrm{E}-01$ & 7.43E-01 \\
\hline & $\%$ & & $35 \%$ & $2 \%$ & $35 \%$ & $0 \%$ & $-31 \%$ & $50 \%$ & $40 \%$ \\
\hline \multirow{2}{*}{$\begin{array}{l}\text { Human } \\
\text { toxicity, cancer } \\
\text { effects (HTc) }\end{array}$} & CTUh & $1.17 \mathrm{E}-08$ & $1.58 \mathrm{E}-08$ & $1.19 \mathrm{E}-08$ & $1.58 \mathrm{E}-08$ & $1.17 \mathrm{E}-08$ & $8.00 \mathrm{E}-09$ & $1.75 \mathrm{E}-08$ & $1.63 \mathrm{E}-08$ \\
\hline & $\%$ & & $36 \%$ & $2 \%$ & $36 \%$ & $0 \%$ & $-31 \%$ & $50 \%$ & $40 \%$ \\
\hline \multirow{2}{*}{$\begin{array}{l}\text { Human } \\
\text { toxicity, non- } \\
\text { cancer effects } \\
\text { (HT-nc) }\end{array}$} & CTUh & $2.14 \mathrm{E}-07$ & $3.00 \mathrm{E}-07$ & 2.19E-07 & $3.00 \mathrm{E}-07$ & $2.14 \mathrm{E}-07$ & $1.38 \mathrm{E}-07$ & $3.36 \mathrm{E}-07$ & $3.11 \mathrm{E}-07$ \\
\hline & $\%$ & & $40 \%$ & $2 \%$ & $40 \%$ & $0 \%$ & $-36 \%$ & $57 \%$ & $45 \%$ \\
\hline \multirow{2}{*}{$\begin{array}{l}\text { Acidification } \\
\text { (AC) }\end{array}$} & $\begin{array}{c}{\text { molc } \mathrm{H}^{+}}_{\mathrm{eq}}\end{array}$ & $5.69 \mathrm{E}-03$ & $7.71 \mathrm{E}-03$ & $5.81 \mathrm{E}-03$ & 7.71E-03 & $5.69 \mathrm{E}-03$ & $3.90 \mathrm{E}-03$ & $8.56 \mathrm{E}-03$ & 7.97E-03 \\
\hline & $\%$ & & $36 \%$ & $2 \%$ & $36 \%$ & $0 \%$ & $-31 \%$ & $50 \%$ & $40 \%$ \\
\hline \multirow{2}{*}{$\begin{array}{l}\text { Freshwater } \\
\text { eutrophication } \\
\text { (FE) }\end{array}$} & $\mathrm{kg} \mathrm{P}$ eq & $2.91 \mathrm{E}-04$ & $4.32 \mathrm{E}-04$ & $2.99 \mathrm{E}-04$ & $4.32 \mathrm{E}-04$ & $2.91 \mathrm{E}-04$ & $1.66 \mathrm{E}-04$ & 4.92E-04 & $4.51 \mathrm{E}-04$ \\
\hline & $\%$ & & $49 \%$ & $3 \%$ & $49 \%$ & $0 \%$ & $-43 \%$ & $69 \%$ & $55 \%$ \\
\hline \multirow{2}{*}{$\begin{array}{l}\text { Marine } \\
\text { eutrophication } \\
\text { (ME) }\end{array}$} & $\mathrm{kg} \mathrm{N} \mathrm{eq}$ & $6.45 \mathrm{E}-03$ & $1.01 \mathrm{E}-02$ & $7.65 \mathrm{E}-03$ & $8.73 \mathrm{E}-03$ & $6.45 \mathrm{E}-03$ & 4.42E-03 & $1.13 \mathrm{E}-02$ & $1.05 \mathrm{E}-02$ \\
\hline & $\%$ & & $57 \%$ & $19 \%$ & $35 \%$ & $0 \%$ & $-31 \%$ & $75 \%$ & $63 \%$ \\
\hline \multirow{2}{*}{$\begin{array}{l}\text { Freshwater } \\
\text { ecotoxicity } \\
\text { (FET) }\end{array}$} & CTUe & 40.81 & 56.53 & 41.77 & 56.53 & 40.81 & 26.92 & 63.11 & 58.55 \\
\hline & $\%$ & - & $39 \%$ & $2 \%$ & $39 \%$ & $0 \%$ & $-34 \%$ & $55 \%$ & $43 \%$ \\
\hline \multirow{2}{*}{ Land use (LU) } & $\begin{array}{l}\mathrm{kg} \mathrm{C} \\
\text { deficit }\end{array}$ & 17.51 & 23.72 & 17.89 & 23.72 & 17.51 & 12.01 & 26.33 & 24.52 \\
\hline & $\%$ & & $35 \%$ & $2 \%$ & $35 \%$ & $0 \%$ & $-31 \%$ & $50 \%$ & $40 \%$ \\
\hline \multirow{2}{*}{$\begin{array}{l}\text { Water resource } \\
\text { depletion (WD) }\end{array}$} & $\begin{array}{c}\mathrm{m}^{3} \\
\text { water eq }\end{array}$ & $2.74 \mathrm{E}-04$ & $3.72 \mathrm{E}-04$ & $2.80 \mathrm{E}-04$ & $3.72 \mathrm{E}-04$ & $2.74 \mathrm{E}-04$ & $1.88 \mathrm{E}-04$ & $4.12 \mathrm{E}-04$ & $3.84 \mathrm{E}-04$ \\
\hline & $\%$ & & $36 \%$ & $2 \%$ & $36 \%$ & $0 \%$ & $-31 \%$ & $50 \%$ & $40 \%$ \\
\hline \multirow{2}{*}{$\begin{array}{l}\text { Mineral, fossil } \\
\& \text { ren resource } \\
\text { depletion } \\
\text { (MFD) }\end{array}$} & $\mathrm{kg} \mathrm{Sb}$ eq & $3.09 \mathrm{E}-06$ & 4.19E-06 & $3.16 \mathrm{E}-06$ & 4.19E-06 & $3.09 \mathrm{E}-06$ & $2.12 \mathrm{E}-06$ & 4.65E-06 & 4.33E-06 \\
\hline & $\%$ & & $36 \%$ & $2 \%$ & $36 \%$ & $0 \%$ & $-31 \%$ & $50 \%$ & $40 \%$ \\
\hline
\end{tabular}


Table 6 Life Cycle Impact Assessment results calculated for the current spring barley production (baseline) and alternative future scenarios (S1-S5) in absolute terms and including the deviation from current sprig barley production, referred to $1 \mathrm{~kg} \mathrm{CP}$ as functional unit.

\begin{tabular}{|c|c|c|c|c|c|c|c|}
\hline Impact category & Unit & Baseline & S1 & $\mathbf{S 2}$ & S3 & S4 & S5 \\
\hline \multirow{2}{*}{$\begin{array}{l}\text { Climate change } \\
(\mathrm{CC})\end{array}$} & $\mathrm{kg} \mathrm{CO} 2 \mathrm{eq}$ & 3.96 & 4.97 & 3.73 & 4.97 & 3.68 & 2.54 \\
\hline & $\%$ & - & $26 \%$ & $-6 \%$ & $26 \%$ & $-7 \%$ & $-36 \%$ \\
\hline \multirow{2}{*}{$\begin{array}{l}\text { Human toxicity, } \\
\text { cancer effects } \\
\text { (HTc) }\end{array}$} & CTUh & $8.68 \mathrm{E}-08$ & $1.09 \mathrm{E}-07$ & $8.18 \mathrm{E}-08$ & $1.09 \mathrm{E}-07$ & $8.06 \mathrm{E}-08$ & $5.53 \mathrm{E}-08$ \\
\hline & $\%$ & - & $26 \%$ & $-6 \%$ & $26 \%$ & $-7 \%$ & $-36 \%$ \\
\hline \multirow{2}{*}{$\begin{array}{l}\text { Human toxicity, } \\
\text { non-cancer } \\
\text { effects (HT-nc) }\end{array}$} & CTUh & $1.59 \mathrm{E}-06$ & $2.07 \mathrm{E}-06$ & $1.5 \mathrm{E}-06$ & $2.07 \mathrm{E}-06$ & $1.48 \mathrm{E}-06$ & $9.52 \mathrm{E}-07$ \\
\hline & $\%$ & - & $30 \%$ & $-5 \%$ & $30 \%$ & $-7 \%$ & $-40 \%$ \\
\hline \multirow{2}{*}{$\begin{array}{l}\text { Acidification } \\
\text { (AC) }\end{array}$} & molc $\mathrm{H}+\mathrm{eq}$ & $4.23 \mathrm{E}-02$ & $5.33 \mathrm{E}-02$ & $3.99 \mathrm{E}-02$ & $5.33 \mathrm{E}-02$ & $3.93 \mathrm{E}-02$ & $2.70 \mathrm{E}-02$ \\
\hline & $\%$ & - & $26 \%$ & $-6 \%$ & $26 \%$ & $-7 \%$ & $-36 \%$ \\
\hline \multirow{2}{*}{$\begin{array}{l}\text { Freshwater } \\
\text { eutrophication } \\
(\mathrm{FE})\end{array}$} & $\mathrm{kg} \mathrm{P}$ eq & $2.16 \mathrm{E}-03$ & $2.99 \mathrm{E}-03$ & $2.06 \mathrm{E}-03$ & $2.99 \mathrm{E}-03$ & $2.01 \mathrm{E}-03$ & $1.14 \mathrm{E}-03$ \\
\hline & $\%$ & - & $38 \%$ & $-5 \%$ & $38 \%$ & $-7 \%$ & $-47 \%$ \\
\hline \multirow{2}{*}{$\begin{array}{l}\text { Marine } \\
\text { eutrophication } \\
\text { (ME) }\end{array}$} & $\mathrm{kg} \mathrm{N} \mathrm{eq}$ & $4.80 \mathrm{E}-02$ & $7.01 \mathrm{E}-02$ & $5.26 \mathrm{E}-02$ & $6.04 \mathrm{E}-02$ & $4.45 \mathrm{E}-02$ & $3.06 \mathrm{E}-02$ \\
\hline & $\%$ & - & $46 \%$ & $10 \%$ & $26 \%$ & $-7 \%$ & $-36 \%$ \\
\hline \multirow{2}{*}{$\begin{array}{l}\text { Freshwater } \\
\text { ecotoxicity (FET) }\end{array}$} & CTUe & 303.67 & 390.64 & 286.85 & 390.64 & 282.05 & 186.00 \\
\hline & $\%$ & - & $29 \%$ & $-6 \%$ & $29 \%$ & $-7 \%$ & $-39 \%$ \\
\hline \multirow{2}{*}{ Land use (LU) } & kg C deficit & 130.28 & 163.95 & 122.84 & 163.95 & 121.01 & 83.02 \\
\hline & $\%$ & - & $26 \%$ & $-6 \%$ & $26 \%$ & $-7 \%$ & $-36 \%$ \\
\hline \multirow{2}{*}{$\begin{array}{l}\text { Water resource } \\
\text { depletion }(\mathrm{WD})\end{array}$} & m3 water eq & $2.04 \mathrm{E}-03$ & $2.57 \mathrm{E}-03$ & $1.92 \mathrm{E}-03$ & $2.57 \mathrm{E}-03$ & $1.90 \mathrm{E}-03$ & $1.30 \mathrm{E}-03$ \\
\hline & & - & $26 \%$ & $-6 \%$ & $26 \%$ & $-7 \%$ & $-36 \%$ \\
\hline \multirow{2}{*}{$\begin{array}{l}\text { Mineral, fossil \& } \\
\text { ren resource } \\
\text { depletion (MFD) }\end{array}$} & $\mathrm{kg} \mathrm{Sb}$ eq & $2.30 \mathrm{E}-05$ & $2.89 \mathrm{E}-05$ & $2.17 \mathrm{E}-05$ & $2.89 \mathrm{E}-05$ & $2.14 \mathrm{E}-05$ & $1.47 \mathrm{E}-05$ \\
\hline & $\%$ & - & $26 \%$ & $-6 \%$ & $26 \%$ & $-7 \%$ & $-36 \%$ \\
\hline
\end{tabular}

